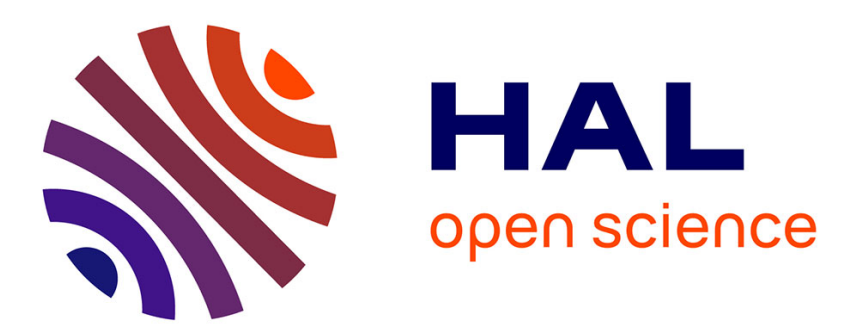

\title{
The Benefits and Costs of Geographic Diversification in Banking
}

\author{
Céline Meslier-Crouzille, Donald P. Morgan, Katherine Samolyk, Amine
}

Tarazi

\section{> To cite this version:}

Céline Meslier-Crouzille, Donald P. Morgan, Katherine Samolyk, Amine Tarazi. The Benefits and Costs of Geographic Diversification in Banking. Journal of International Money and Finance, 2016, 69, pp.287-317. hal-01338717

\section{HAL Id: hal-01338717 https: / hal-unilim.archives-ouvertes.fr/hal-01338717}

Submitted on 29 Jun 2016

HAL is a multi-disciplinary open access archive for the deposit and dissemination of scientific research documents, whether they are published or not. The documents may come from teaching and research institutions in France or abroad, or from public or private research centers.
L'archive ouverte pluridisciplinaire HAL, est destinée au dépôt et à la diffusion de documents scientifiques de niveau recherche, publiés ou non, émanant des établissements d'enseignement et de recherche français ou étrangers, des laboratoires publics ou privés. 


\title{
The Benefits and Costs of Geographic Diversification in Banking
}

\author{
Céline Meslier \\ Université de Limoges, LAPE \\ Donald P. Morgan \\ Federal Reserve Bank of New-York, USA \\ Katherine Samolyk \\ Consumer Financial Protection Bureau, USA \\ Amine Tarazi \\ Université de Limoges, LAPE
}

The authors' views do not necessarily reflect those of their employers

\begin{abstract}
We estimate the benefits of geographic diversification within states and across states for bank risk and return for all U.S. bank holding companies over 1994 to 2008, and assess whether such benefits depend on bank size.For small banks, only intrastate diversification increases risk-adjusted returns and reduces default risk while for very large institutions only interstate expansions are beneficial but only in terms of default risk. In all cases the relationship ishumpshaped indicating that at some point, the possible agency costs associated with banks getting wider and more geographically diversified outweigh the benefits.Our results indicate that small banks and very large banks could still benefit from further geographic diversification.
\end{abstract}

JEL Classification: G21, G28

Keywords: bank geographic diversification, risk, return, agency costs

Email Addresses:

celine.meslier@unilim.fr (Céline Meslier),Don.Morgan@ny.frb.org (Donald P. Morgan) katherine.Samolyk@cfpb.gov (Katherine Samolyk), tarazi@unilim.fr (Amine Tarazi).

The views herein do not necessarily reflect those of the Federal Reserve System. 


\section{Introduction}

Consolidation in the U.S. banking industry has made U.S. banks not just larger, but also wider. The largest bank holding companies (BHCs) now operate across multiple states and smaller ones now do business across multiple markets and counties within states. Compared to the vast literature on growing size and scale, this wideningand the potential geographic diversification it provides hasbeen relatively neglected. ${ }^{1}$ We document trends in geographic diversification for BHCs and investigate how such diversification affects their risk and return while controlling for scale.

While scale and width are obviously related, scale is a production concept while diversification is a portfolio concept. Accordingly, we imagine banks as a portfolio of loans and we treat improved opportunities to diversify geographically, due to deregulation for example, as an upward shift in the risk-return tradeoff facing a bank. Importantly,an improvement in that return tradeoff does notnecessarily lead to lower risk; depending on their preferences, some banks may respond to the improved returns to risk-taking by increasing risk, albeit with greater returns (Demsetz and Strahan 1997). How risk varies with improved diversification opportunities depends on a bank's appetite for risk, but in any case, riskadjusted returns (e.g. the Sharpe (1994) ratio) should increase with diversification, all else equal.Any gains from diversification may diminish, or even become costs, if agency conflicts between BHC headquarters and branch management increase sufficiently with the distance between them (Berger and DeYoung (2001), Deng and Elyasiani (2008), Goetz et al. (2013)). We allow for that possibility byestimating a general, quadratic relationship between our measures of geographic diversification, on the one hand, and various performance measures on the other.

Like Deng and Elyasiani (2008) and Goetz (2012), we measure geographic diversification using the FDIC's annual Summary of Deposits, wherein banks annually report the amount of their deposits at all their U.S. branches.Deposit diversification is of course only a proxy for loan diversification, but given the abundance of evidence that small business and

\footnotetext{
${ }^{1}$ As a somewhat crude measure of that neglect: A Google Scholar search of the phrase "economies of scale in banking" yields 817 hits while a search for "geographic diversification in banking" yields 111 hits. Without the quotes, the respective tally is 1.2 million vs. 71 thousand.
} 
consumer lending, and to a lesser extent mortgage lending, are still very local (Peterson and Rajan (2002),Agarwal and Hauswald (2010)) we maintain that is a reasonable proxy.We measure diversification across states (interstate diversification) and across MSAs (Metropolitan Statistical Areas) and rural counties within states (intrastate) over 19942006. ${ }^{2}$ Looking within BHCs, we estimate how geographic diversification relates to various measures of risk, returns, and risk-adjusted returns while controlling for a host of other variables, including diversification across loan types and income sources.

We find that for small banks, only intrastate diversification is beneficial both in terms of risk-adjusted returns and default risk.For very large institutions only interstate expansionsarerewardingbut only in terms of default risk. However, in all cases the relationship ishump-shaped for both intrastate and interstate diversification indicating limits for banks of all size. Our results indicate that both small banks and very large bank could still benefit from further geographic diversification.

Our findings contribute to the recent research on geographic diversification in banking.Deng and Elyasiani (2008) study 505, large publically traded, U.S. banks and find that greater geographic diversification is associated with increased market value and reduced risk. Goetz et al., (2013) also focus on publically traded banks but do not look at risk. While these studies are limited to public BHCs with book value of assets averaging more than 10 billion of dollars, our paper coversessentially all U.S. banks - public and private. Extending the analysis to include smaller private banks is useful because shareholders of public banks can diversify by holding shares in banks all over the country but smaller, private banks may need to physically spread their operations across the state or across the country to diversify. If the owners of such small banks have a large portion of their wealth invested in the bank they will not be able to hold enough shares in other banks. Other studies look at the effect on risk for small banks located in one state (Goetz, 2012) or small community banks (Emmons et al., 2004) but do not investigate the impact of geographic diversification on small banks' riskreturn tradeoff. By considering the broadest possible sample of banks, our aim is to investigate the potential benefits of diversification at various size levels and multiple geographic

\footnotetext{
${ }^{2}$ We start in 1994 to capture the diversification trends following the Riegle-Neal Interstate Banking Act of 1994. We end in 2006 to avoid disruptions brought on by the global financial crisis. For further insights, we also separately consider the 2007-2008 period.
} 
dimensions encompassing the case of a small bank initially operating in a single county or MSA and reaching for new business only a few miles away to the largest institutions spreading across states and internationally.

The remainder of the paper is organized as follows. Section 2relates our work to previous literature and discusses our research focus. Section 3 presents the data and section 4 our empiricalmodeland results. Section 5 concludes.

\section{Related literature}

The widening of U.S. banks and the accompanying geographic diversification has been a gradual process over decades. Starting in the 1970s, as individual states began letting banks branch across their own state, and compacts of states began allowing interstate bank mergers among the states in the compact. In 1982, BHCs were allowed (by the Garn-St. Germain Act) to buy failedbanks in any state, regardless of state laws. Before 1994, virtually all mergers involved two banks in the same state, often a healthy bank buying a failing one. The Interstate Banking Act of 1994 (Riegle-Neal) enables BHCs to buy any bank - healthy or not —in any state.

Riegle-Neal essentially made interstate banking a bank right rather than a state right and hastened the widening and diversification of U.S banks. ${ }^{3}$ This process was accomplished in large part through mergers, both within state and across states. As noted earlier, the potential efficiency gains associated with greater scale via mergers has been studied at great length. ${ }^{4}$ Our focusis on the other dimension of scale-width- and the possible diversification benefits arising from it. Although our analysis accounts for mergers, we do not study the merger process itself.

\footnotetext{
${ }^{3}$ See Strahan (2003) for a thorough review of the deregulation driving intrastate branching and interstate banking. ${ }^{4}$ DeYoung et al. (2009) review 150 studies after 2000 on bank mergers gains. In general, the early findings suggested that gains for U.S. banks were quite limited.Dietsch and Oung (2001) draw a similar conclusion from their study of bank mergers in France: "... market-driven merger strategies based on cost synergies do not seem to be empirically justified. On the other hand, there seems to be an underused potential for income synergies and risk diversification gains." More recent research for U.S. banks, do find evidence of economies of scale, even for very large banks (Wheelock and Wilson2012).
} 
With their focus on scale, researchers have largely ignored the potential geographic diversification benefits of consolidation in the banking industry.This disinterest may be partly theory based; investors can hold shares in large, public banks all over the country, so they may not need banks to diversify themselves. Shareholders may even penalize diversification at the firm level if it reduces pressures on managers to perform well. The diversification "discount" for non-financial firms (where the whole firm is worth less than its parts) suggests that investors prefer focused firms where managers stick to their core business. Laeven and Levine (2007) find a diversification discount in the banking industry, indicating that economies of scope are not sufficiently large to produce a diversification premium and to outweigh the costs associated to agency problems. Of course, diversification is a core business in bankingso it seems plausible to expect some upside for better diversified banks. Diversification may also improve banks' investment by smoothing internal cash flows through internal capital markets thereby avoidinghigher external funding costs (Houston, James, and Marcus 1997). ${ }^{5}$

Geographic diversification may also create costs (Goetz et al. 2013). When opening branches in a new county or state, banks face learning costs due to the lack of information on this new market. These costs can be particularly high for banks which specialize in relationship lending such as community banks. As banks geographically expand, collecting soft information becomes more costly as the distance between the lender and the borrower increases and the transmission of this information across the different management layers becomes more difficult. Moreover, getting wider puts distance between principals (executives and owners) and agents (management) and hence wider banks may face higher agency costs. Costs associated with geographic diversification could hence be different for banks with different business models. As discussed in Stein (2002), lending technologies based on soft information will face decreasing returns to scale but lending technologies relying on hard information can be more easily scaled up.

Though neglected, researchers have not ignored geographic diversification entirely. In their study of listed BHCs, Demsetz and Strahan (1997) findthat the largest BHCs were more diversified across census regions, and that such diversification was associated with lower stock

\footnotetext{
${ }^{5}$ With the advent of diversified asset backed securities (ABS) a bank may be able to diversify geographically without physically spreading out across space. Of course there are still many important asset classes (small business loans, personal loans, installment loans, etc.) that are not securitized, but to the extent ABS obviates physical geographic diversification, we will tend to find no effect.
} 
return volatility. Among Italian banks, Acharya et al (2006) find that geographic diversification improves the risk return tradeoff, at least for relatively safe banks. Assessing the effects of geographic expansion on bank efficiency with a sample of 7000 banks from 1993 to 1998, Berger and DeYoung (2001) find mixed results; expansion to nearby states or regions tends to increase bank efficiency, but inefficiencies tend to increase with the distance between a bank holding company's headquarters and its subsidiaries, possibly due to increasing agency costs.

The negative impact of distance on the diversification discount is also reported by Deng and Elyasiani (2008) in terms of higher diversification discount and higher risk. Using a sample of 505listed BHCs, they analyze the link between geographic diversification and BHC value and risk by focusing on the distance between headquarters and branches. While increased geographic diversification enhances bank value and reduces risk, larger distance generates a diversification discount and higher risk. Hence, the diseconomies associated with distance may limit the gains from geographic diversification.Goetz et al. (2013) also find a negative relationship between geographic diversity, following interstate bank deregulation, and BHC value. According to the authors, this result could reflect agency costs; larger diversity makes it more difficult for outside investors to control insiders which allows them to extract larger private benefits from the bank. Nevertheless, by further exploring the potential benefits of technological progress in the banking industry, Berger and DeYoung (2006) highlight how these changes have facilitated the geographic expansion of U.S. banks by reducing distance-related agency costs and by improving the control of parent banks on their subsidiaries. Benefits of geographic diversification could also result from higher competition in local banking markets. As highlighted by Evanoff and Ors (2008), geographic deregulation in the U.S. had a positive effect on bank efficiency. By increasing competition in local markets, entry of new competitors, through mergers and acquisitions, leads incumbent banks, not involved in the process, to reduce their costs and hence improve their cost efficiency. Moreover, bank diversification could also affect the risk-taking behavior of local nondiversified competitors. Indeed, Goetz (2012) highlight that bank diversification tends to increase bank risk-taking but lowers competitors' risk-taking. 
Although portfolio theory would predictthat geographically concentrated banks would be riskier than geographically diversified banks, there is no clear-cut empirical evidence on the vulnerability of U.S. banks'to local economic shocks. Meyer and Yeager (2001) do not find a significant link between bank performance and local economic conditions. Moreover, focusing on community banks located in a single county, Yeager (2004) does not find local economic shocks (which are independent from state or nationwide economic conditions)to systematically impair bank performance.If banks are not actually affected by local economic shocks, the potential benefits of geographic diversification, particularly for community banks may be questioned. Using a technique ofsimulating mergers, Emmons et al. (2004) investigate the ability of small community banks (i.e. with a total assets less than \$400 million USD) to reduce default risk through scale effects and geographic diversification. The authors concludethat benefits of geographic diversification for small community banks are small. As idiosyncratic risk dominates local market risk in small community banks, they could reduce failure risk through increasing size, by acquiring other banks in the same market they operate.However, for small community banks located in urban markets, benefits of geographic diversification are greater, reflecting higher heterogeneity in economic conditions across U.S. urban areas than rural areas. Our question iswhether greater geographic diversification is been associated with higher risk-adjusted returns and lowerdefault risk.We expect a positive relationship between diversification and risk-adjusted returns up to a point, after which the potential costs (agency, learning, etc.)could outweigh the benefits and cause a negative relationship between risk-adjusted returns and diversification.Moreover, whether risk increases or decreases with diversification will depend on the risk strategies pursued by diversifying banks. If they switch towards riskier strategies their default risk could increase even if their risk-adjusted returns are higher.

\section{Data}

\subsection{Data and sample}

Our data are from Bank Call Reports and FDIC's Summary of Deposits (SOD). The initialsample comprises BHCs and banks are not affiliated with a BHC leading to an unbalanced panel of 10,681 banks with a total of 92,550 annual observations. In our main 
investigation we use data from1994 to 2006,starting with the Interstate Banking Act of 1994 (Riegle-Neal) and ending before the global financial crisis triggered in 2007 to avoid atypical disruptions. We also conduct estimations during the peak of the crisis by separately considering the 2007-2008 period. ${ }^{6}$ We measure all variables at the holding-company level, i.e. we treat all banks affiliated with a holding company as a single entity. ${ }^{7}$ Measuring at the bank level instead would ignore the diversification provided via affiliation with banks in other locations. We exclude credit card banks, wholesale banks, or other special purpose entities. Diversification may matter for such institutions, but because they do not operate deposit networks, deposit data are not a good proxy for their geographic diversification. ${ }^{8} \mathrm{We}$ exclude banks that have not filed Call Reports for at least five years. To account for bank mergers and acquisitions, we follow Stiroh and Rumble (2006) andidentify banks whose total assets have grown by more than $30 \%$ between any two consecutive yearsexcluding three-year windows around the merger because we use the time dimension to compute some of our risk measures.

\subsection{Diversification measures and trends}

We measure geographic diversification using an inverse concentration measure of deposits across each banks' branches. Specifically, geographic diversification for bank iin year tequals: ${ }^{9}$

$$
\mathrm{GD}_{\mathrm{it}}=1-\Sigma_{\mathrm{j}}\left(\text { Deposits }_{\mathrm{j}} / \text { Total Deposits }\right)^{2}
$$

\footnotetext{
${ }^{6}$ As noted by an anonymous referee, investigating the post-crisis period would have been very instructive. Unfortunately, because our risk and risk-adjusted return variables require historical data for computation (rolling-window standard deviations) we are limited by the time dimension of the data available post-crisis. ${ }^{7}$ We aggregate data for commercial banks that are affiliated with the same holding company into BHC-level measures for each "market". For commercial banks that arethe holding company (i.e., the only commercial bank affiliate), the BHC and bank data are the same.

${ }^{7} \mathrm{We}$ aggregate data for commercial banks that are affiliated with the same holding company into BHC-level measures for each "market". For commercial banks that arethe holding company (i.e., the only commercial bank affiliate), the BHC and bank data are the same.

${ }^{8}$ We identify wholesale banks using Community Reinvestment Act (CRA) data that identifies whether an institution is considered a wholesale bank for CRA assessment purposes. The Home Mortgage Disclosure Act (HMDA) and CRA data are calendar year data. Here we also use year-end BHC data. Since the Summary of Deposits (SOD) data are reported for June of each year, we merger adjust these data to reflect the year-end bank and BHC-affiliates status before constructing our geographic diversification indices.

${ }^{9}$ Unless otherwise noted, we use "bank" and "BHC" interchangeably.
} 
Where Deposits $\mathrm{j}$ equals deposits of bank i in location $\mathrm{j}$ at time $\mathrm{t}$ and Total Deposits equals total deposits of bank $\mathrm{i}$ at time t.GDvaries between 0 (a bank with all its deposits in a single branch) to one (a bank with its deposits spread widely (infinitely) across many branches. The branch deposit data are from the annual Summary of Deposits collected by the Federal Deposit Insurance Corporation.

We measure geographic diversification at both the "local" and state level. GD1measures diversification across 2600 Metropolitan Statistical Area (MSAs)and all nonMSA counties. This intrastate measure corresponds to the "local market" concept used in antitrust analysis and the literature on market structure and performance.GD2measures interstate diversification across the 50 states.

\section{Insert Table 1}

Table 1 and Figure 1 reveal that the average U.S. bank has indeed become widersince 1994. The mean of GD1 (intrastate diversification)almost doubled between 1994 and 2006: from 0.104 to 0.190. GD2 (interstate diversification) also increased, although less substantially. While diversification has increased, most banks remain highly undiversified: in 2006, more than 50 percent of banks still operated in a single county and more than 75 percent in a single state.

To disentangle the effect of geographic diversification and size within relatively homogenous bank subsets, we assess the effect of geographic diversification using three subsamplesof banks stratified by size (assets). Following the literature,we define "small banks"as those with assets of $\$ 1$ billion or less, "large banks,"with total assets above $\$ 1$ billion and below $\$ 10$ billion, and "very largebanks"with total assets of $\$ 10$ billion or more.

\subsection{Bank profitability and risk measures}

To measure bank profitability, we use the return on assets $\left(\mathrm{ROA}_{\mathrm{it}}\right)$ and the return on equity $\left(\mathrm{ROE}_{\mathrm{it}}\right)$ :

$$
\mathrm{ROA}_{\mathrm{it}}=\frac{\text { Net income }_{\mathrm{it}}}{\text { Total assets }}
$$




$$
\mathrm{ROE}_{\mathrm{it}}=\frac{\text { Net income }_{\text {it }}}{\text { Total equity }_{\mathrm{it}}}
$$

To measure bank risk-takingwe use the standard deviation of the return on assets, $\left(\mathrm{SdROA}_{\mathrm{it}}\right)$ and the standard deviation of the return on equity, $\left(\mathrm{SdROE}_{\mathrm{it}}\right)$ computed on a rolling window of 3 years. ${ }^{10}$ For robustness, we also use an alternative measure which captures the quality of the loan portfolio: the ratio of net loan and lease chargeoffs to total loans (CRED_RISK it $_{\text {). }}$.

We measure risk-adjusted returnsusing the ratio of $\mathrm{ROA}_{\mathrm{it}}$ to its standard deviation $\mathrm{SdROA}_{\mathrm{it}}, \mathrm{RaROA}_{\mathrm{it}}$ and the ratio of $\mathrm{ROE}_{\mathrm{it}}$ to its standard deviation $\mathrm{SdROE}_{\mathrm{it}}, \mathrm{RaROE}_{\mathrm{it}}$ :

$$
\begin{aligned}
& \operatorname{RaROA}_{i t}=\frac{\mathrm{ROA}_{i t}}{\mathrm{SdROA}_{i t}} \\
& \operatorname{RaROE}_{i t}=\frac{\mathrm{ROE}_{\mathrm{it}}}{\mathrm{SdROE}_{\mathrm{it}}}
\end{aligned}
$$

We also consider bank default risk using a 3-year rolling Z-score defined as:

$$
\mathrm{Z}_{\mathrm{it}}=\frac{\overline{\mathrm{ROA}_{\mathrm{it}}}+\overline{\mathrm{EQUITY}_{\mathrm{it}}}}{\mathrm{SdROA}_{\mathrm{it}}}
$$

where EQUITY is the ratio of total equity to total assets and $\overline{\mathrm{ROA}}$ and $\overline{\mathrm{EQUITY}}$ are backward moving averages of ROA and EQUITY over a 3-year rolling window. The Z-score indicates the number of standard deviations that a bank's ROA has to fall below its expected value before equity is depleted. Thus, a higher value of $\mathrm{Z}$ is associated with a lower default probability.

In our regressions, we exclude observations below the $1^{\text {st }}$ and above the $99^{\text {th }}$ percentile of our bank profitability, risk-adjusted returns and bank risk measures to mitigate the influence of outliers. We end up with a panel of 6,532 banks and a total of 65,381bank-year observations.

\footnotetext{
${ }^{10}$ The rolling windows cover the current and two previous years.
} 


\subsection{Control variables}

CONTROL $_{\mathrm{it}}$ includes a number of control variables. First, bank-specific variablesare included to account fordifferences in portfolio diversification and functional diversification. Two product diversification indexes $\left(\mathrm{LOAN}_{\mathrm{it}}\right.$ and FOREIGN $\left._{\mathrm{it}}\right)$ and one functional diversification index (INCOME ${ }_{i t}$ ) are computed. Diversification indexes across the major loan categories $\left(\mathrm{LOAN}_{\mathrm{it}}\right)$, across foreignand domestic loans $\left(\mathrm{FOREIGN}_{\mathrm{it}}\right)$, and across interest and non-interest income sources ( $\mathrm{INCOME}_{\mathrm{it}}$ ) for each bankare measured analogously:

$$
\operatorname{LOAN}_{\mathrm{it}}=1-\Sigma_{\mathrm{j}=1-6}^{\mathrm{j}}\left(\text { Loans }_{\mathrm{j}} / \text { Total loans }\right)^{2}
$$

FOREIGN $_{\mathrm{it}}=1-\left((\text { Foreign loans/Total loans })^{2}+(\text { Domestic loans/Total loans })^{2}\right)$

$$
\mathrm{INCOME}_{\mathrm{it}}=1-\left((\text { Non-interest income/Income })^{2}+(\text { Interest income/Income })^{2}\right)
$$

Loan diversification $\left(\mathrm{LOAN}_{\mathrm{it}}\right)$ is measured across the six major loan categories (Loans $\mathrm{j}_{\mathrm{j}}$ reported in the Call Reports. ${ }^{11}$ The non-interest activities measured by INCOME $_{\text {it }}$ include any fee-generating activities by banks(as opposed to interest), e.g. underwriting, payment services, trading activities, etc. Stiroh and Rumble (2006) find that a higher share of non-interest income in total income is associated with higher volatility of bank returns. In principle, foreign diversification $\left(\right.$ FOREIGN $\left._{\mathrm{it}}\right)$ should operate on risk and return in the same way as domestic diversification across the U.S. We also include liquidity risk LIQUID_RISK ${ }_{\text {it }}$, (Core deposits/Total assets), leverage, EQUITY it, (Total equity/Total assets)in the estimations.

We include dummy variables for main bank loan specialization (agricultural loan, mortgage specialists, consumer-oriented, etc.) and to distinguish some specific types of banks (banks which are part of a holding company from independent banks and agricultural lending institutions). We also take into account the specific characteristics of our sample regarding geographic diversification/concentration. Because more than half of the banks in our sample

\footnotetext{
${ }^{11}$ Commercial and industrial, commercial real estate, home mortgages, consumer, agricultural, and other.
} 
operate in a single county and more than $90 \%$ are located in a single state, we include in our estimations two dummy variables which take the value of 1 if the bank is located in a single county (SINGLECOUNTY) ${ }^{12}$ or a single state(SINGLESTATE) respectively. We also include time effects but while these time effects are constant across banks but could differ across states, we also control for state-level specific effects. We use annual information on countylevel unemployment rates and compute an indicator of 'within-state' economic disparities, $\left(\mathrm{SDUNEMP}_{\mathrm{st}}\right)$. This variable is the dispersion of unemployment rates across the counties of a given state sat time $\mathrm{t}$.

Tables 2.1 to 2.4 provide statistics for the full sample and three sub-samples.

Insert Tables 2.1 to 2.4

Not surprisingly, the extent of geographic diversification varies substantiallyby banksize. Over $50 \%$ of small banks operate in only asingle county and more than $90 \%$ operate in a single state. By contrast,more than half of large banks and nearly all very large banks operate in multiple states.

Table 3reports descriptive statistics for diversified and non-diversified banks. Diversified banks tend to be larger and more profitable. Their loan portfolio is also more diversified and they are involved in a broader set of business lines. Moreover, diversified banks exhibit higher risk-adjusted returns but also higher levels of default risk. Such differences are statistically significant at the $1 \%$ level.

\section{Insert Table 3}

\footnotetext{
${ }^{12}$ We do not include this variable in the estimations on the sub-sample of very large banks as they are all located in more than one county.
} 
Given the high correlation between geographic diversification and size, to avoidcolinearity,we orthogonalizethe logarithm of total assets against each GD measure and use the residuals as our size proxy (SIZE).

\section{Econometric model and results}

\subsection{Econometric model}

Our baseline model is as follows:

$\mathrm{Y}_{\mathrm{it}}=\propto_{\mathrm{i}}+\propto_{\mathrm{T}}+\beta_{1} \mathrm{GD}_{\mathrm{it}}+\beta_{2} \mathrm{GD}_{\mathrm{it}}{ }^{2}+\theta_{1} \operatorname{SIZE}_{\mathrm{it}}+\delta \mathrm{CONTROL}_{\mathrm{it}}+\varepsilon_{\mathrm{it}}$

$\mathrm{Y}_{\mathrm{it}}$ measureseither bank returns (ROA or ROE) or risk (Z-score or standard deviation of returns). $\alpha_{\mathrm{i}}$ and $\alpha_{\mathrm{T}}$ are respectively the individual/bank effects and time-specific effects. $\mathrm{GD}_{\mathrm{it}}$ is one of the two measures of geographic diversification of bank $i$ at time $t\left(G D 1_{i t}\right.$ or $\left.G D 2_{i t}\right)$. SIZE $_{i t}$ equals the $\log$ of assets of bank $i$ at time t,orthogonalized with respect to the diversification measures.

The quadratic specification allows for $U$ (or humped) shaped relationships between geographic diversification and the dependent variables; we expect diversification to increase risk-adjusted returns up to some point,beyond whichit could have negative effects due to distance-related information and agency costs. Moreover, differences in size and business model could also affect geographic diversification benefits. Lending technologies which rely on soft information may be harder to extend to new locations than those based on hard information.Hence, when expanding beyond their core market, small banks and more specifically community banks specialized in relationship lending may face higher costs than larger banks which rely on transaction-based lending technologies.

We measure the impact of increased diversification on each outcomeusing the marginal effect evaluated at the mean of GD $(\overline{\mathrm{GD}})$ : 


$$
\frac{\partial \mathrm{Y}_{\mathrm{it}}}{\partial \mathrm{GD}_{\mathrm{it}}}=\beta_{1}+2 \beta_{2} \overline{\mathrm{GD}}(2)
$$

The decision to expand across counties or across states might be partly endogenous; better performing banks might be more likely to expand or more risk averse bank owners might be more inclined to diversify geographically.To avoid bias, we estimate equation (1) using the instrumental variables. For both diversification measures the instruments include two lagged values of the measures themselves and their squared values. For the intrastate diversification (GD1)we also use the number of years since a state first remove its intrastate branching restrictions. For interstate diversification (GD2), we use the number of years since a state first began liberalizing its interstate banking laws. Starting with Jayaratne and Strahan (1998), the deregulation dates have been widely used in the banking literature to identify how exogenous changes in banking structure and competition affect both bank and economic performance. For example, Goetz (2012) uses the intrastate deregulation dates in studying how diversification induced by regulatory changes affects bank outcome and market structure.

\subsection{Results}

Results for the full sample of banks are reported in Table 5. ${ }^{13}$ For intrastate diversification (first panel), both GD and GD squared enter significantly in every regression except for SdROA. The opposing pattern of coefficients implies a hump-shaped relationship between geographic diversification and ROA, risk-adjusted ROA and ROE, and LogZ. That hump shape suggests that diversifying geographically across MSA and counties within a state initially increases returns and reduces default risk default but that beyond some point is associated with reduced returns and higher default risk. Although the relationships are humpshaped, the marginal effects of on GD on ROA, RaROA, RaROE, and Z-scores are positive and significant, implying that for a bank at the average level of diversification across a state, spreading into another MSA or ruralcounty would increase returns and lower default risk. The point estimates imply a sizable impact; a standard deviationincrease in GDlincreases RaROE

\footnotetext{
${ }^{13}$ The first stage regressions (available upon request) indicate a positive and significant effect of deregulation on both intrastate and interstate expansion. Kleibergen-Paap tests and Hansen J-statistic indicate that our instruments are valid. For brevity, we only report results for ROA and SdROA. Results for ROE and SdROE are similar (available upon request).
} 
by 8.8 percent and reduces default risk (i.e. increases $\log Z$ ) by 3.6 , with both effects measured relative to average. ${ }^{14}$

The results for interstate diversification (GD2) are in the right panel. RaROA and SdROA are not significantly related to GD2, but ROA and RaROE are both significantly related to GD2 in the same hump-shaped pattern as for GD1. The marginal effect of GD2 on both variables is positive, implying a gain in returns for the average bank in diversifying to another state. By contrast with GD1, GD2 is monotonically and positively related to LogZ.

Overall, the results full sample are consistent with our expectations. We find benefits from intrastate and interstate geographic diversification on ROA, risk-adjusted ROA, and default risk up to a point, after which the agency costs, leaning costs, or other downsides associated with distance turns those benefits into costs. Nevertheless, the average bank would gain in both return and risk reduction from a marginal increase in diversification.

The results for the subsample of banks (small, large, and very and large) are in Table 6.We find intrastate and interstate geographic diversification to have a different effect on riskadjustedreturn and bank risk according to bank size. Firstly, we find a hump-shaped relationship between intrastate diversification and both profitability and risk-adjustedreturn for small banks. We further find a non-linear effect of intrastate expansion on default risk.A one standard increase in intrastate diversification (0.215) leads to an increase in risk-adjusted return $(\mathrm{RaROE})$ of 1.81 and a decrease of default risk $(\log Z)$ of 0.20 where the mean of riskadjusted return and of default risk are 9.61 and 4.36 respectively. At low levels of diversification the impact on default risk is negative but such benefits are limited when diversification is stronger. However, we do not find any significant effect of interstate diversification. These results are consistent with the U.S banking industry consolidation process which occurred during the second part of the 1990s. As pointed out by DeYoung and Hunter (2003), and Emmons et al., (2004), the bulk of mergers are "mini-mergers" which involved small/community banks, in most cases located nearby. As these new markets are nearby their own local market, small banks do not face sharp increases in monitoring and learning costs. Such an expansion allows them to reduce their idiosyncratic risk and to improve their risk/return tradeoff. At the other extreme, for very large banks (i.e. with total

\footnotetext{
${ }^{14}$ A one standard deviation increase in GD1 is associated with an increase of 2.08 in RaROA, or 20 percent compare to its mean.
} 
assets above $\$ 10$ billion) we find a significant impact of interstate diversification on bank default riskbut again the relationship is hump-shaped indicating that such benefits are limited. However, while this effect is statistically significant, the economic significance remains relatively low. A one standard increase in interstate diversification (0.275) lead a decrease of very large banks default risk of 0.07 . However, we do not find any significant effect for large banks (those with total assets ranging from $\$ 1$ billion to $\$ 10$ billion).

The marginal effect of intrastate diversification on risk-adjusted return is positive and significant for small banks, indicating that intrastate expansion is still beneficial for small banks. Moreover, our results show that further interstate expansion might allow very large banks to reduce their default risk. We also highlight the other sources of diversification to have different effects on risk-adjusted returns and risk according to bank size. While income diversification reduces risk-adjusted returns and increases risk (both earnings volatility and default risk) for small banks, it reduces risk for very large banks. For very large banks, default risk is also negatively associated with diversification across loan categories. ${ }^{15}$

Our results clearly reveal a non-linearimpact of geographic diversification. Whereas at one extreme, intrastate geographic expansion positively affects small banks' riskadjustedreturn and reduces their risk, at the other extreme, interstate diversification allows very large banks to reduce their default risk. But, in between, geographic diversification does not appear to be beneficial.Such limits in the benefits of geographic diversification for larger banks are consistent with the findingsof Deng and Elyasiani (2008) who highlight a reduction in BHC value and an increase in bank risk with higher distance between headquarter and branches. Similar conclusions are highlighted by Goetz et al. (2013) who show thathigher geographic diversification due to interstate deregulation is associated with a reduction in $\mathrm{BHC}$ value.

\footnotetext{
${ }^{15}$ For the sub-samples of small and large banks, test statistics mostly conclude to the validity and the strength of our set of instruments. For large banks, in three cases, the results of the weak identification test indicates a reduction in the strength of instrumentation. As estimators can perform poorly when instruments are weak, we reestimate equation (1) using the limited-information maximum likelihood (LIML) estimator which is more robust to weak instruments. Results are qualitatively similar and do not highlight any significant effect of geographic expansion for large banks. For the subsample of very large banks, our instruments are valid and strong (weak IV and over identification tests) regarding interstate diversification but to a lesser extent for intrastate diversification. We therefore also use the LIML estimator and find qualitatively similar results.
} 


\subsection{Further issues and robustness checks}

After the 2008 financial crisis the Federal Reserve has distinguished very large and systemically important institutions from other large banks with a threshold of $\$ 50$ billion (FED, 2011). We hence also consider a sub-sample of systemic banks (total assets of $\$ 50$ billion and above). We run IV regressions for this sub-sample and do not find any significant impact of both intrastate and interstate diversification. As systemic banks have already reached a high level of both intrastate and interstate diversification, further expansion within the U.S. might not be beneficial anymore. To investigate the possible influence played by the global financial crisis of 2007-2008, we conduct estimations for the 2007-2008 ${ }^{16}$. All in all, the results indicate that the benefits of diversification are apparently weaker during this troubled period. The results of the regressions on the whole sample of banks (small and large) no longer show any significant impact of geographic diversification on risk-adjusted return (Table A1). Nevertheless, intrastate diversification still affects default risk but interstate diversification no longer matters. A closer investigation using the different size sub-samples shows that small banks no longer benefit from diversification in terms of risk-adjusted return although their default risk is still reduced, although at the $10 \%$ level only (Table A2). Because of data limitations, the estimations could not be carried out for the very large and systemic banks.

The intrastate diversification measure treats all rural counties separately, even if they are adjacent. That may overstate the risk mitigating effects of diversification if the covariance of economic activity across adjacent rural countiesis high. Accordingly, we estimated the model using alternative measure of intrastate diversification that counts individual MSAs separately, but treats non-MSA counties as a single entity, yielding 380 entities in total. While we still do not find any significant effect of intrastate diversification for both large banks and very large banks, small banks benefit from diversification across MSA counties (Tables A3 and A4).

Our initial sample includes BHCs and non-BHC commercial banks. Excluding the latter does not change our main findings (Tables A5 and A6).

As an alternative risk measure, we use the ratio of net charges off of loans and leases to total loans (CRED_RISK). Thisvariable captures the quality of the loan portfolio of the bank. We find a hump-shaped relationship between intrastate diversification and credit risk for small

\footnotetext{
${ }^{16}$ Due to data limitations, we perform these estimations using the OLS estimator.
} 
banks. The initial steps toward diversification, decreases the quality of bank's portfolio while further expansion tend to attenuate this effect.This might be explained by a geographic diversification behavior which have led small banks to first expand in nearby contiguous regions, characterized by a strong correlation in economic activity. As highlighted by Berger et al. (1999), DeYoung and Hunter, 2003 and Berger et al. 2004, the bulk of mergers which occurred during the second part of the 1990s are "mini-mergers" which involved small/community banks, in most cases located nearby (Emmons et al., 2004). Therefore, moving forward their core markets do not allow small banks to fully benefit from the access to these new markets and to reduce their risk. Further expansions in non-contiguous markets with non-synchronized economic conditionsmay allow small banks to benefit from disparities in economicconditions and hence increase their loan portfolio quality. The overall effect of credit risk is positive and significant. A one standard deviation of intrastate diversification leads to an increase of small banks' credit risk of 0.0007. Mean credit risk is 0.003 , so the magnitude is small (Table A7).

\section{Conclusion}

This paper contributes to the literature on bank diversification by focusing on the benefits of geographic diversification. Since 1994, U.S. banks have strongly expanded their activities across counties and across states. Our findings clearly highlight some benefits from being presentin more counties within the same state as well as across states. We use detailed data spanning the period 1994, when the Riegle-Neal Interstate Banking Act was introduced, to 2006, prior to the global financial crisis and also separately investigate the two years of the peak of the crisis (2007-2008). We consider bank geographic diversification from the extreme case of institutions with operations limited to a single location (individual Metropolitan Statistical area (MSA) or individual county) to the case where customers are reached nationwide. While (either intrastate or interstate) geographic diversification is, on the whole, beneficial in terms of risk-adjusted return, the effects are non-linear and depend on bank size. While at low levels of diversification spreading across counties or across states improves 
banks' risk-adjusted return, this positive effect turns out to be negative when geographic diversification moves further up. Moreover, whatever its scope, geographic expansion significantly reduces bank risk. Our results indicate that, on average,small banks (i.e. with total assets below $\$ 1$ billion) have still not reached their optimal diversification level. But small banks can only gain from diversification within their state In between, medium size or large banks (i.e. with total assets between $\$ 1$ billion and $\$ 10$ billion) will not benefit from further diversification. 


\section{References}

Acharya, V., I., Hasan, A., Saunders. 2006. Should Banks Be Diversified? Evidence from Individual Bank Loan Portfolios, The Journal of Business, 79, 1355-1412.

Agarwal, Sumit and Robert Hauswald. 2010. Distance and Private Information in Lending, Review of Financial Studies. 23 (7),2757-2788

Berger, A., N., DeYoung R., 2001. The Effects of Geographic Expansion on Bank Efficiency.Journal of Financial Services Research 19, 163-184.

Berger, A., N., S., D., Bonime, L., G., Goldberg, L., J., White, 2004. The Dynamics of Market Entry: The effects of Mergers and Acquisitions on De Novo Entry and Small Business Lending in the Banking Industry,Journal of Business, 77 (4).

Berger, A., N., DeYoung R., 2006. Technological progress and the geographic expansion of commercial banks. Journal of Money, Credit, and Banking 38 (6),1483-1513

Berger, A., N., Demsetz,R., S., Strahan, P., E., 1999.The consolidation of the financial services industry: Causes, consequences, and implications for the future.Journal of Banking and Finance 23 (2-4), 135-194.

Demsetz,R., S., Strahan, P., E., 1997. Diversification, Size, and Risk at Bank Holding Companies. Journal of Money, Credit, and Banking, 29.

Deng, S., E., Elyasiani, E., 2008. Geographic Diversification, Bank Holding Company Value and Risk. Journal of Money Credit and Banking 40 (6), 1217-38.

DeYoung, R., Evanoff,D., D., Molyneux, P., 2009. Mergers and Acquisition of Financial Institutions: A Review of the Post-2000 Literature. Journal of Financial Services Research 36, 87-110.

DeYoung, R., Hunter, W., C., 2003. Deregulation, the Internet, and the Competitive Viability of Large Banks and Community Banks.In Benton Gup (Eds.), The Future of Banking, Westport, CT/ Quorum Books, 173-202.

Dietsch, M., Oung, V., 2001. The Formation of Large Banking Groups in France: Observed and Potential Effects on Costs, Income, and Risks. General Secretariat of the Banking Commission. 
Emmons, W. R., Gilbert, R., A., Yeager, T., J., 2004. Reducing the Risk at Small Community Banks: Is it Size or Geographic Diversification that Matters?. Journal of Financial Services Research 25(2/3), 259-281.

Evanoff D., D., Ors, E., 2008. The Competitive Dynamics of Geographic Deregulation in Banking: Implications for Productive Efficiency. Journal of Money Credit and Banking 40 (5), 897-928.

Federal Register, 2011. Proposed rules, Federal Reserve, 76,7731-7740.

Goetz, M., Laeven, L., Levine, R., 2013. The Valuation Effect of Geographic Diversification: Evidence from US Banks.Review of Financial Studies 26(7), 1787-1823.

Goetz, M., 2012. Bank Diversification, Market Structure and Bank Risk Taking: Theory and Evidence from US Commercial Banks. Federal Reserve Bank of Boston Working Paper QAU12-2.

Houston, J., F., James, C., Marcus, D., 1997.Capital Market Frictions and the Role of Internal Capital Markets in Banking.Journal of Financial Economics 46 (2), 135-164.

Laeven, L., Levine, R., 2007.Is there a diversification discount in financial conglomerates?.Journal of Financial Economics 85(2), 331-367.

Jayaratne, J. and Strahan, P.1998. The Finance-Growth Nexus: Evidence From Bank Branch Deregulation. Quarterly Journal of Economics, 111(3), pp. 639-70.

Meyers, A., P., Yeager, T., J., 2001. Are Small Rural Banks Vulnerable to LocalEconomic Downturns?. Federal Reserve Bank of St. Louis Review 83, 25-38.

Peterson, Mitchell and Ragu Rajan. 2002. Does Distance Still Matter, The Journal of Finance, Vol. LVII, (6), 2533-2570.

Sharpe, William, 1994. The Sharpe Ratio. The Journal of Portfolio Management, 21 (1), 4958.

Stein, J., C., 2002. Information Production and Capital Allocation: Decentralized versus Hierarchical Firms.Journal of Finance 57(5), 1891-1921.

Stiroh, K., J., Rumble, A., 2006. The dark side of diversification: the case of U.S. financial holding companies.Journal of Banking and Finance 30(8), 2131-2161.

Wheelock, D., C., Wilson, P., W., 2012. Do Large Banks have Lower Costs? New Estimates of Return to Scale for U.S. Banks. Journal of Money Credit and Banking 44 (1), 171-199. 
Table 1 Summary Statistics on Intrastate (GD1) and Interstate (GD2) Diversification of U.S. banks ${ }^{1}$

\begin{tabular}{|c|c|c|c|c|c|c|c|c|c|c|}
\hline \multicolumn{11}{|c|}{ 1994-2006 } \\
\hline & Mean & $\begin{array}{l}\text { Standard } \\
\text { deviation }\end{array}$ & Minimum & Maximum & $\mathrm{p} 10$ & $\mathrm{p} 25$ & p50 & p75 & p90 & p99 \\
\hline GD1 & 0.138 & 0.232 & 0 & 0.978 & 0 & 0 & 0 & 0.245 & 0.500 & 0.852 \\
\hline GD2 & 0.013 & 0.076 & 0 & 0.918 & 0 & 0 & 0 & 0 & 0 & 0.481 \\
\hline$N$ & 65381 & & & & & & & & & \\
\hline \multicolumn{11}{|c|}{1994} \\
\hline & Mean & $\begin{array}{l}\text { Standard } \\
\text { deviation }\end{array}$ & Minimum & Maximum & $\mathrm{p} 10$ & $\mathrm{p} 25$ & $\mathrm{p} 50$ & p75 & p90 & p99 \\
\hline GD1 & 0.104 & 0.211 & 0 & 0.955 & 0 & 0 & 0 & 0 & 0.477 & 0.823 \\
\hline GD2 & 0.009 & 0.064 & 0 & 0.856 & 0 & 0 & 0 & 0 & 0 & 0.438 \\
\hline$N$ & 5074 & & & & & & & & & \\
\hline \multicolumn{11}{|c|}{2006} \\
\hline & Mean & $\begin{array}{l}\text { Standard } \\
\text { deviation }\end{array}$ & Minimum & Maximum & $\mathrm{p} 10$ & $\mathrm{p} 25$ & p50 & p75 & $\mathrm{p} 90$ & p99 \\
\hline GD1 & 0.190 & 0.261 & 0 & 0.962 & 0 & 0 & 0 & 0.405 & 0.610 & 0.876 \\
\hline GD2 & 0.023 & 0.098 & 0 & 0.916 & 0 & 0 & 0 & 0 & 0 & 0.551 \\
\hline$N$ & 4248 & & & & & & & & & \\
\hline
\end{tabular}

${ }^{\mathrm{I}}$ GD1 measures diversification across MSAs and non- MSA counties. GD2 measures diversification across states. pi: $\mathrm{i}^{\text {th }}$ percentile. 
Figure 1: Intrastate diversification (1994 - 2006)

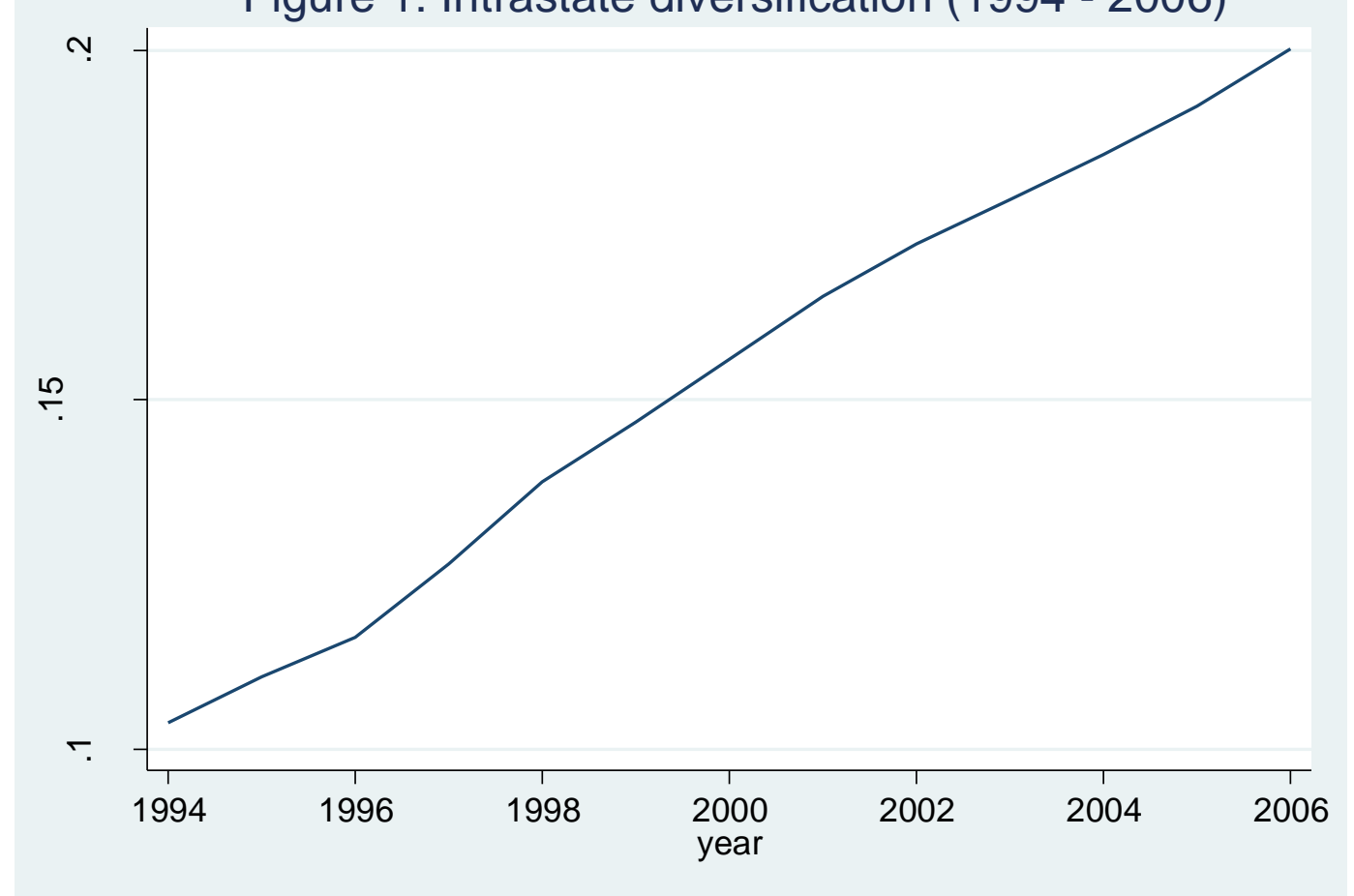




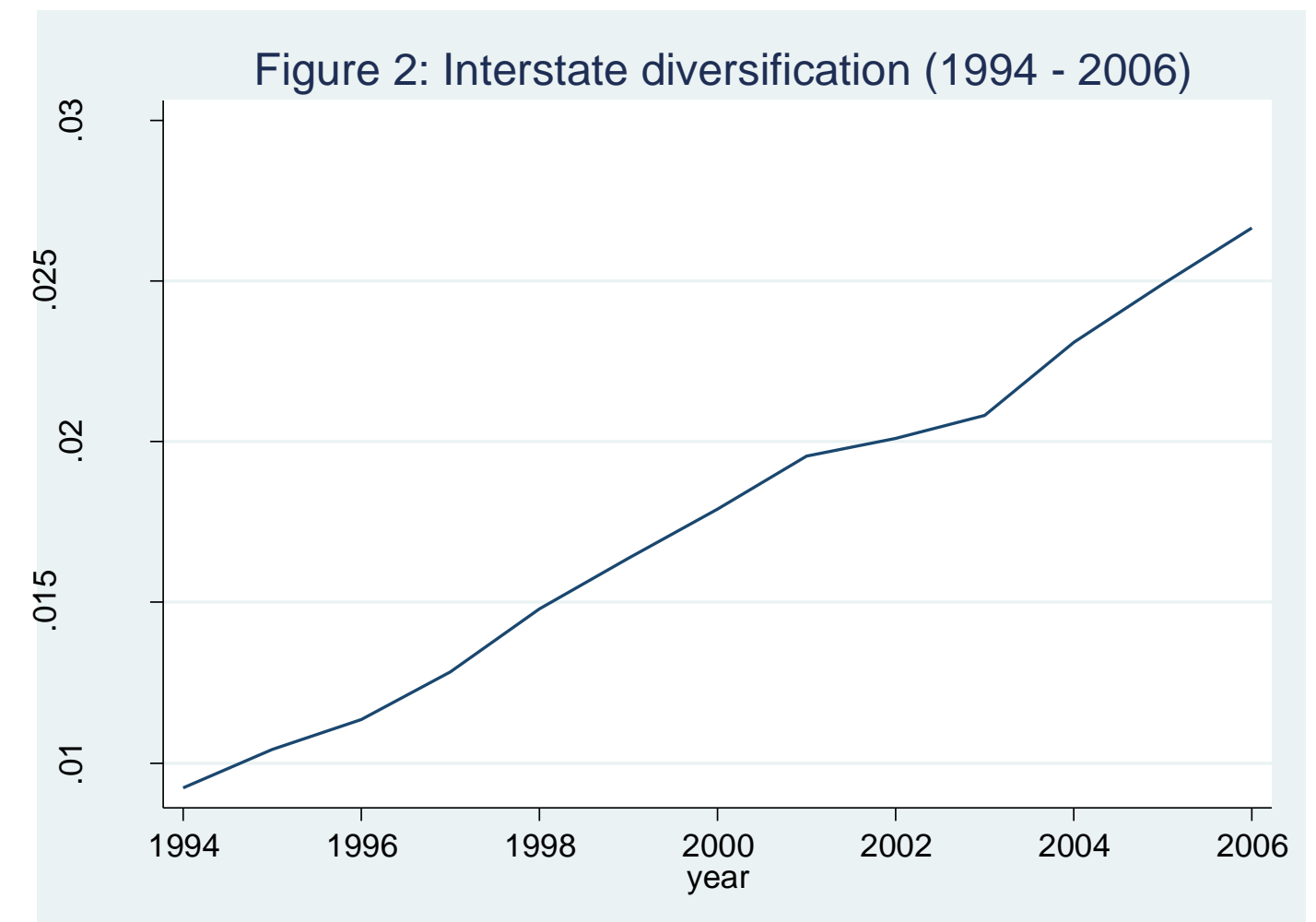


Table 2.1Descriptive statistics - Whole sample ${ }^{1}$

\begin{tabular}{|c|c|c|c|c|c|c|c|c|c|}
\hline & Mean & $\begin{array}{c}\text { Standard } \\
\text { Deviation }\end{array}$ & Minimum & Maximum & p10 & $\mathrm{p} 25$ & p50 & p75 & p90 \\
\hline \multicolumn{10}{|c|}{ Bank-level variables } \\
\hline ROA & 0.011 & 0.005 & -0.011 & 0.028 & 0.005 & 0.008 & 0.011 & 0.014 & 0.017 \\
\hline ROE & 0.115 & 0.049 & -0.039 & 0.265 & 0.055 & 0.082 & 0.113 & 0.146 & 0.181 \\
\hline SdROA & 0.002 & 0.002 & 0.0001 & 0.016 & 0.0004 & 0.0007 & 0.001 & 0.002 & 0.004 \\
\hline SdROE & 0.020 & 0.018 & 0.001 & 0.127 & 0.004 & 0.007 & 0.01 & 0.025 & 0.043 \\
\hline RaROA & 10.11 & 7.355 & 0.894 & 34.62 & 2.654 & 4.590 & 7.977 & 13.70 & 21.13 \\
\hline RaROE & 9.713 & 6.711 & 1.143 & 31.16 & 2.769 & 4.594 & 7.865 & 13.13 & 19.99 \\
\hline $\mathrm{Z}$ & 121.8 & 127.0 & 5.320 & 923.1 & 25.43 & 44.18 & 80.75 & 148.2 & 264.2 \\
\hline $\log Z$ & 4.367 & 1.014 & -2.999 & 10.26 & 3.150 & 3.743 & 4.366 & 4.995 & 5.608 \\
\hline GD1 & 0.138 & 0.232 & 0 & 0.978 & 0 & 0 & 0 & 0.245 & 0.500 \\
\hline GD2 & 0.013 & 0.075 & 0 & 0.918 & 0 & 0 & 0 & 0 & 0 \\
\hline INCOME & 0.249 & 0.091 & 0 & 0.500 & 0.137 & 0.185 & 0.242 & 0.307 & 0.372 \\
\hline FOREIGN & 0.0008 & 0.016 & 0 & 0.500 & 0 & 0 & 0 & 0 & 0 \\
\hline LOAN & 0.691 & 0.109 & 0 & 1.000 & 0.549 & 0.654 & 0.722 & 0.763 & 0.789 \\
\hline EQUITY & 0.105 & 0.035 & -0.015 & 0.767 & 0.073 & 0.082 & 0.096 & 0.117 & 0.147 \\
\hline LIQUID_RISK & 0.737 & 0.093 & 0.002 & 0.979 & 0.620 & 0.688 & 0.751 & 0.802 & 0.839 \\
\hline $\log (\mathrm{TA})$ & 11.38 & 1.252 & 6.957 & 20.38 & 9.964 & 10.56 & 11.27 & 12.03 & 12.85 \\
\hline \multicolumn{10}{|c|}{ State level macroeconomic variable } \\
\hline SDUNEMP & 1.879 & 1.191 & 0 & 9.157 & 0.771 & 1.096 & 1.624 & 2.403 & 3.287 \\
\hline
\end{tabular}

${ }^{1}$ From 1994 (Interstate Banking Act) to 2006 (before the global financial crisis of 2007-2008). ROA: Net income/Total assets; ROE: Net income/Total equity; SdROA is the 3year window standard deviation of ROA ; SdROE is the 3-year window standard deviation of ROE; RaROA: ROA/SdROA; RaROE: ROE/SdROE; Z: 3-year rolling Z-score; $\log Z$ : $\log$ of Z-score; GD1: across rural and MSA counties geographic diversification index; GD2: across states geographic diversification index; INCOME: diversification index across interest and non-interest income; FOREIGN: diversification index across domestic and foreign loans; LOAN: diversification index across major loans categories; EQUITY: Total equity/Total assets; LIQUID_RISK: Core deposits/Total assets;Log(TA): natural logarithm of Total assets(TA); N: number of observations; n: number of banks; pi: $i^{\text {th }}$ percentile.SDUNEMP: Standard deviation of unemployment rates across the counties of a given state $s$ at time $t$. 
Table 2.2 Descriptive statistics - Small banks (Total Assets $\leq \$ 1$ billion) ${ }^{1}$

\begin{tabular}{lccccccccc}
\hline & Mean & $\begin{array}{c}\text { Standard } \\
\text { Deviation }\end{array}$ & Minimum & Maximum & p10 & p25 & p50 & p75 & p90 \\
\hline ROA & 0.011 & 0.005 & -0.011 & 0.028 & 0.005 & 0.008 & 0.011 & 0.014 & 0.017 \\
ROE & 0.114 & 0.049 & -0.039 & 0.265 & 0.0548 & 0.081 & 0.111 & 0.144 & 0.179 \\
SdROA & 0.002 & 0.002 & 0.0001 & 0.016 & 0.0004 & 0.0008 & 0.001 & 0.002 & 0.004 \\
SdROE & 0.020 & 0.018 & 0.001 & 0.127 & 0.004 & 0.007 & 0.014 & 0.025 & 0.043 \\
RaROA & 10.00 & 7.309 & 0.894 & 34.62 & 2.622 & 4.541 & 7.870 & 13.53 & 20.90 \\
RaROE & 9.609 & 6.658 & 1.143 & 31.16 & 2.744 & 4.546 & 7.772 & 12.96 & 19.75 \\
Z & 121.0 & 126.6 & 5.320 & 923.1 & 25.28 & 43.81 & 80.11 & 147.2 & 262.5 \\
LogZ & 4.361 & 1.011 & -2.999 & 10.26 & 3.147 & 3.738 & 4.359 & 4.989 & 5.601 \\
GD1 & 0.124 & 0.215 & 0 & 0.917 & 0 & 0 & 0 & 0.204 & 0.491 \\
GD2 & 0.007 & 0.051 & 0 & 0.686 & 0 & 0 & 0 & 0 \\
INCOME & 0.245 & 0.088 & 0 & 0.500 & 0.136 & 0.183 & 0.239 & 0.302 & 0.364 \\
FOREIGN & 0.0004 & 0.012 & 0 & 0.500 & 0 & 0 & 0 & 0 \\
LOAN & 0.690 & 0.109 & 0 & 1.000 & 0.546 & 0.653 & 0.721 & 0.762 & 0.789 \\
EQUITY & 0.105 & 0.035 & -0.015 & 0.767 & 0.074 & 0.083 & 0.096 & 0.118 & 0.148 \\
LIQUID_RISK & 0.741 & 0.088 & 0.003 & 0.979 & 0.628 & 0.692 & 0.753 & 0.803 & 0.840 \\
log(TA) & 11.24 & 1.016 & 6.957 & 13.81 & 9.945 & 10.53 & 11.22 & 11.92 & 12.61 \\
\hline N =62999 & $\mathrm{n}=6370$ & & & & & & & 0 \\
\hline
\end{tabular}

${ }^{1}$ From 1994 (Interstate Banking Act) to 2006 (before the global financial crisis of 2007-2008). ROA: Net income/Total assets; ROE: Net income/Total equity; SdROA is the 3year window standard deviation of ROA; SdROE is the 3-year window standard deviation of ROE; RaROA: ROA/SdROA; RaROE: ROE/SdROE; Z: 3-year rolling Z-score; $\log Z$ : $\log$ of Z-score; GD1: across rural and MSA counties geographic diversification index; GD2: across states geographic diversification index; INCOME: diversification index across interest and non-interest income; FOREIGN: diversification index across domestic and foreign loans; LOAN: diversification index across major loans categories; EQUITY: Total equity/Total assets; LIQUID_RISK: Core deposits/Total assets; Log(TA): natural logarithm of Total assets (TA); N: number of observations; n: number of banks; pi: $i^{\text {th }}$ percentile. 
Table 2.3 Descriptive statistics - Large banks (\$1Billion $<$ Total assets $<\$ 10$ Billion $)^{1}$

\begin{tabular}{|c|c|c|c|c|c|c|c|c|c|}
\hline & Mean & $\begin{array}{c}\text { Standard } \\
\text { Deviation }\end{array}$ & Minimum & Maximum & $\mathrm{p} 10$ & $\mathrm{p} 25$ & $\mathrm{p} 50$ & $\mathrm{p} 75$ & p90 \\
\hline ROA & 0.012 & 0.004 & -0.009 & 0.027 & 0.008 & 0.010 & 0.0125 & 0.014 & 0.017 \\
\hline ROE & 0.143 & 0.043 & -0.039 & 0.265 & 0.091 & 0.117 & 0.142 & 0.171 & 0.198 \\
\hline SdROA & 0.001 & 0.001 & 0.0001 & 0.016 & 0.0003 & 0.0005 & 0.0009 & 0.0017 & 0.003 \\
\hline SdROE & 0.016 & 0.015 & 0.001 & 0.127 & 0.004 & 0.006 & 0.012 & 0.020 & 0.034 \\
\hline RaROA & 12.99 & 8.018 & 0.895 & 34.27 & 4.019 & 6.680 & 11.25 & 18.10 & 25.37 \\
\hline RaROE & 12.46 & 7.422 & 1.146 & 31.08 & 3.910 & 6.559 & 10.88 & 17.32 & 23.64 \\
\hline Z & 145.7 & 137.6 & 6.182 & 921.3 & 34.01 & 56.84 & 100.4 & 184.6 & 321.4 \\
\hline $\log Z$ & 4.510 & 1.066 & -0.037 & 8.315 & 3.237 & 3.875 & 4.536 & 5.166 & 5.789 \\
\hline GD1 & 0.489 & 0.335 & 0 & 0.978 & 0 & 0.144 & 0.561 & 0.800 & 0.886 \\
\hline GD2 & 0.140 & 0.209 & 0 & 0.861 & 0 & 0 & $2.22 \mathrm{e}-16$ & 0.253 & 0.485 \\
\hline INCOME & 0.338 & 0.091 & 0.030 & 0.500 & 0.213 & 0.275 & 0.345 & 0.405 & 0.456 \\
\hline FOREIGN & 0.006 & 0.040 & 0 & 0.496 & 0 & 0 & 0 & 0 & 0 \\
\hline LOAN & 0.722 & 0.093 & 0.023 & 0.965 & 0.612 & 0.693 & 0.746 & 0.781 & 0.800 \\
\hline EQUITY & 0.089 & 0.023 & 0.046 & 0.289 & 0.069 & 0.077 & 0.085 & 0.096 & 0.109 \\
\hline LIQUID_RISK & 0.647 & 0.123 & 0.002 & 0.895 & 0.498 & 0.582 & 0.664 & 0.731 & 0.785 \\
\hline $\log (\mathrm{TA})$ & 14.74 & 0.898 & 13.59 & 17.44 & 13.84 & 14.02 & 14.46 & 15.26 & 16.14 \\
\hline
\end{tabular}

${ }^{1}$ From 1994 (Interstate Banking Act) to 2006 (before the global financial crisis of 2007-2008). ROA: Net income/Total assets; ROE: Net income/Total equity; SdROA is the 3year window standard deviation of ROA; SdROE is the 3-year window standard deviation of ROE; RaROA: ROA/SdROA; RaROE: ROE/SdROE; Z: 3-year rolling Z-score; $\operatorname{logZ}$ : $\log$ of Z-score; GD1: across rural and MSA counties geographic diversification index; GD2: across states geographic diversification index; INCOME: diversification index across interest and non-interest income; FOREIGN: diversification index across domestic and foreign loans; LOAN: diversification index across major loans categories; EQUITY: Total equity/Total assets; LIQUID_RISK: Core deposits/Total assets;Log(TA): natural logarithm of Total assets (TA); N: number of observations; n: number of banks; pi: $i^{\text {th }}$ percentile. 
Table 2.4 Descriptive statistics - Very large banks (Total assets $\geq \$ 10$ Billion) ${ }^{1}$

\begin{tabular}{|c|c|c|c|c|c|c|c|c|c|}
\hline & Mean & $\begin{array}{c}\text { Standard } \\
\text { Deviation }\end{array}$ & Minimum & Maximum & p10 & p25 & $\mathrm{p} 50$ & p75 & p90 \\
\hline ROA & 0.013 & 0.003 & 0.004 & 0.025 & 0.010 & 0.011 & 0.013 & 0.015 & 0.016 \\
\hline ROE & 0.157 & 0.030 & 0.057 & 0.236 & 0.124 & 0.141 & 0.158 & 0.178 & 0.190 \\
\hline SdROA & 0.001 & 0.001 & 0.0002 & 0.006 & 0.0003 & 0.0007 & 0.001 & 0.002 & 0.004 \\
\hline SdROE & 0.019 & 0.017 & 0.002 & 0.087 & 0.003 & 0.007 & 0.014 & 0.026 & 0.048 \\
\hline RaROA & 11.56 & 7.473 & 1.576 & 34.52 & 3.291 & 5.780 & 9.475 & 15.92 & 22.65 \\
\hline RaROE & 12.15 & 7.844 & 1.648 & 30.95 & 3.436 & 5.497 & 10.53 & 18.41 & 23.58 \\
\hline Z & 106.3 & 92.13 & 12.43 & 520.1 & 23.65 & 44.98 & 73.09 & 135.2 & 248.2 \\
\hline $\log Z$ & 4.289 & 0.947 & 1.877 & 8.021 & 3.058 & 3.714 & 4.242 & 4.895 & 5.477 \\
\hline GD1 & 0.752 & 0.277 & 0.017 & 0.970 & 0.130 & 0.674 & 0.896 & 0.936 & 0.951 \\
\hline GD2 & 0.577 & 0.275 & 0 & 0.918 & 0.053 & 0.423 & 0.690 & 0.789 & 0.846 \\
\hline INCOME & 0.452 & 0.042 & 0.275 & 0.500 & 0.391 & 0.432 & 0.461 & 0.489 & 0.498 \\
\hline FOREIGN & 0.092 & 0.155 & 0 & 0.500 & 0 & 0.0003 & 0.020 & 0.090 & 0.439 \\
\hline LOAN & 0.772 & 0.057 & 0.597 & 0.940 & 0.684 & 0.748 & 0.781 & 0.799 & 0.834 \\
\hline EQUITY & 0.085 & 0.016 & 0.056 & 0.163 & 0.067 & 0.075 & 0.084 & 0.095 & 0.104 \\
\hline LIQUID_RISK & 0.523 & 0.128 & 0.120 & 0.757 & 0.359 & 0.471 & 0.550 & 0.597 & 0.662 \\
\hline $\log (\mathrm{TA})$ & 18.31 & 0.783 & 17.32 & 20.38 & 17.51 & 17.73 & 18.11 & 18.67 & 19.70 \\
\hline
\end{tabular}

${ }^{1}$ From 1994 (Interstate Banking Act) to 2006 (before the global financial crisis of 2007-2008). ROA: Net income/Total assets; ROE: Net income/Total equity; SdROA is the 3 year window standard deviation of ROA; SdROE is the 3-year window standard deviation of ROE; RaROA: ROA/SdROA; RaROE: ROE/SdROE; Z: 3-year rolling Z-score; $\operatorname{logZ}$ : $\log$ of Z-score; GD1: across rural and MSA counties geographic diversification index; GD2: across states geographic diversification index; INCOME: diversification index across interest and non-interest income; FOREIGN: diversification index across domestic and foreign loans; LOAN: diversification index across major loans categories; EQUITY: Total equity/Total assets; LIQUID_RISK: Core deposits/Total assets;Log(TA): natural logarithm of Total assets (TA); N: number of observations; n: number of banks; pi: $i^{\text {th }}$ percentile. 
Table 3: Comparative descriptive statistics for non-diversified and diversified bank sub-samples ${ }^{1}$

\begin{tabular}{|c|c|c|c|c|c|c|c|c|c|c|}
\hline & \multicolumn{4}{|c|}{ Non-Diversified banks } & \multicolumn{6}{|c|}{ Diversified banks } \\
\hline & Mean & $\begin{array}{c}\text { Standard } \\
\text { Deviation }\end{array}$ & Minimum & "Maximum & p50 & Mean & $\begin{array}{l}\text { Standard } \\
\text { Deviation }\end{array}$ & Minimum & Maximum & $\mathrm{p} 50$ \\
\hline ROA & 0.0113 & 0.005 & -0.011 & 0.028 & 0.011 & 0.0115 & 0.005 & -0.011 & 0.028 & 0.011 \\
\hline ROE & 0.109 & 0.050 & -0.039 & 0.265 & 0.105 & 0.122 & 0.049 & -0.039 & 0.265 & 0.121 \\
\hline SdROA & 0.002 & 0.002 & 0.0001 & 0.016 & 0.001 & 0.002 & 0.002 & 0.0001 & 0.016 & 0.001 \\
\hline SdROE & 0.020 & 0.019 & 0.001 & 0.127 & 0.014 & 0.021 & 0.019 & 0.001 & 0.127 & 0.015 \\
\hline RaROA & 9.780 & 7.243 & 0.896 & 34.62 & 7.655 & 10.23 & 7.484 & 0.894 & 34.57 & 8.044 \\
\hline RaROE & 9.372 & 6.603 & 1.144 & 31.16 & 7.524 & 9.897 & 6.838 & 1.143 & 31.14 & 8.040 \\
\hline $\mathrm{Z}$ & 121.2 & 127.1 & 5.320 & 923.1 & 80.13 & 116.0 & 123.3 & 5.339 & 921.3 & 75.88 \\
\hline INCOME & 0.238 & 0.090 & 0 & 0.500 & 0.230 & 0.275 & 0.088 & 0.0017 & 0.500 & 0.269 \\
\hline FOREIGN & 0.0006 & 0.014 & 0 & 0.500 & 0 & 0.0012 & 0.018 & 0 & 0.500 & 0 \\
\hline LOAN & 0.681 & 0.115 & 0 & 1.000 & 0.712 & 0.715 & 0.091 & 0.023 & 0.952 & 0.740 \\
\hline EQUITY & 0.110 & 0.038 & -0.015 & 0.767 & 0.101 & 0.096 & 0.024 & -0.015 & 0.382 & 0.091 \\
\hline LIQUID_RISK & 0.737 & 0.095 & 0.002 & 0.979 & 0.752 & 0.715 & 0.094 & 0.058 & 0.928 & 0.727 \\
\hline TA & 119340.7 & 228342.5 & 1242 & 13630042 & 64977 & 1985573.2 & 25151482.2 & 6690 & 1610162539 & 178812 \\
\hline
\end{tabular}

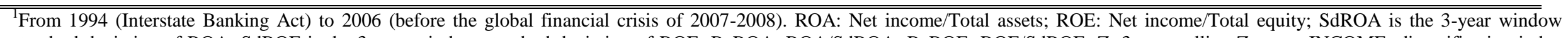

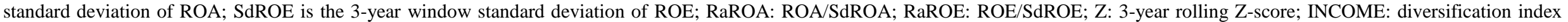

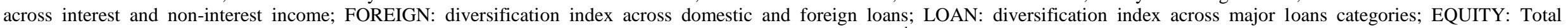
equity/Total assets; LIQUID_RISK: Core deposits/Total assets;TA: Total assets; N: number of observations; pi: $i^{\text {th }}$ percentile. 
Table 4.1: Correlation matrix (GD1)

\begin{tabular}{|c|c|c|c|c|c|c|c|c|c|}
\hline & GD1 & $\mathrm{GD1}^{2}$ & $\log (\mathrm{TA})$ & SIZE & INCOME & FOREIGN & LOAN & EQUITY & LIQUID_RISK \\
\hline GD1 & 1 & & & & & & & & \\
\hline GD1² & 0.950 & 1 & & & & & & & \\
\hline $\log (\mathrm{TA})$ & 0.500 & 0.523 & 1 & & & & & & \\
\hline SIZE & 0.122 & 0.170 & 0.920 & 1 & & & & & \\
\hline INCOME & 0.207 & 0.212 & 0.323 & 0.277 & 1 & & & & \\
\hline FOREIGN & 0.0160 & 0.0180 & 0.162 & 0.178 & 0.0844 & 1 & & & \\
\hline LOAN & 0.165 & 0.160 & 0.193 & 0.147 & 0.259 & 0.0218 & 1 & & \\
\hline EQUITY & -0.174 & -0.150 & -0.227 & -0.182 & -0.262 & -0.0240 & -0.185 & 1 & \\
\hline LIQUID_RISK & -0.110 & -0.116 & -0.359 & -0.361 & -0.0779 & -0.205 & -0.00946 & -0.152 & 1 \\
\hline
\end{tabular}

${ }^{1}$ From 1994 (Interstate Banking Act) to 2006 (before the global financial crisis of 2007-2008). GD1: across rural and MSA counties geographic diversification index; GD12: squared value of GD1; $\log (\mathrm{TA})$ : natural logarithm of Total assets (TA); SIZE: orthogonalized value of $\log (\mathrm{TA})$ with GD1 as measure of geographic diversification;INCOME: diversification index across interest and non-interest income; FOREIGN: diversification index across domestic and foreign loans; LOAN: diversification index across major loans categories; EQUITY: Total equity/Total assets; LIQUID_RISK: Core deposits/Total assets.

Table 4.2: Correlation matrix (GD2) ${ }^{1}$

\begin{tabular}{|c|c|c|c|c|c|c|c|c|c|}
\hline & GD2 & $\mathrm{GD}^{2} 2$ & $\log (\mathrm{TA})$ & SIZE & INCOME & FOREIGN & LOAN & EQUITY & LIQUID_RISK \\
\hline GD2 & 1 & & & & & & & & \\
\hline $\mathrm{GD} 2^{2}$ & 0.948 & 1 & & & & & & & \\
\hline $\log (\mathrm{TA})$ & 0.440 & 0.419 & 1 & & & & & & \\
\hline SIZE & 0.274 & 0.261 & 0.984 & 1 & & & & & \\
\hline INCOME & 0.179 & 0.169 & 0.323 & 0.311 & 1 & & & & \\
\hline FOREIGN & 0.0983 & 0.0914 & 0.162 & 0.154 & 0.0844 & 1 & & & \\
\hline LOAN & 0.0719 & 0.0684 & 0.193 & 0.193 & 0.259 & 0.0218 & 1 & & \\
\hline EQUITY & -0.0719 & -0.0599 & -0.227 & -0.229 & -0.262 & -0.0240 & -0.185 & 1 & \\
\hline LIQUID_RISK & -0.151 & -0.141 & -0.359 & -0.354 & -0.0779 & -0.205 & -0.00946 & -0.152 & 1 \\
\hline
\end{tabular}

${ }^{1}$ From 1994 (Interstate Banking Act) to 2006 (before the global financial crisis of 2007-2008). GD2: across state geographic diversification index; GD22: squared value of GD2; $\log (\mathrm{TA})$ : natural logarithm of Total assets (TA); SIZE: orthogonalized value of log (TA) with GD2 as measure of geographic diversification;INCOME: diversification index across interest and non-interest income; FOREIGN: diversification index across domestic and foreign loans; LOAN: diversification index across major loans categories; EQUITY: Total equity/Total assets; LIQUID_RISK: Core deposits/Total assets. 
Table 5: Effect of Geographic Diversification on Bank Risk and Performance

This table reports the IV regression results of our baseline model using GD1 and GD2 respectively as measure of geographic diversification (GD)from 1994 (Interstate Banking Act) to 2006(before the global financial crisis of 2007-2008). Explained variables are ROA, RaROA, RaROE, SdROA and logZ. GD: measures of intrastate diversification orinterstate diversification. Other control: other control variables presented in section 3.4. N: number of observations; $n$ : number of banks. The marginal effect is calculated as the first derivative of the explained variable with respect to the geographic diversification index computed using the average value of the geographic diversification index. NS: not significant.K-P statistic: Kleinberger-Paap rk F statistic for weak instrument; J statistics: Hansen-J statistic of overidentifying restrictions. $t$ statistics in parentheses, ${ }^{*} \mathrm{p}<0.1,{ }^{* * *} \mathrm{p}<0.05,{ }^{* * *} \mathrm{p}<0.01$. All other variables are defined in Table 1.1. All models include bank and year effects.

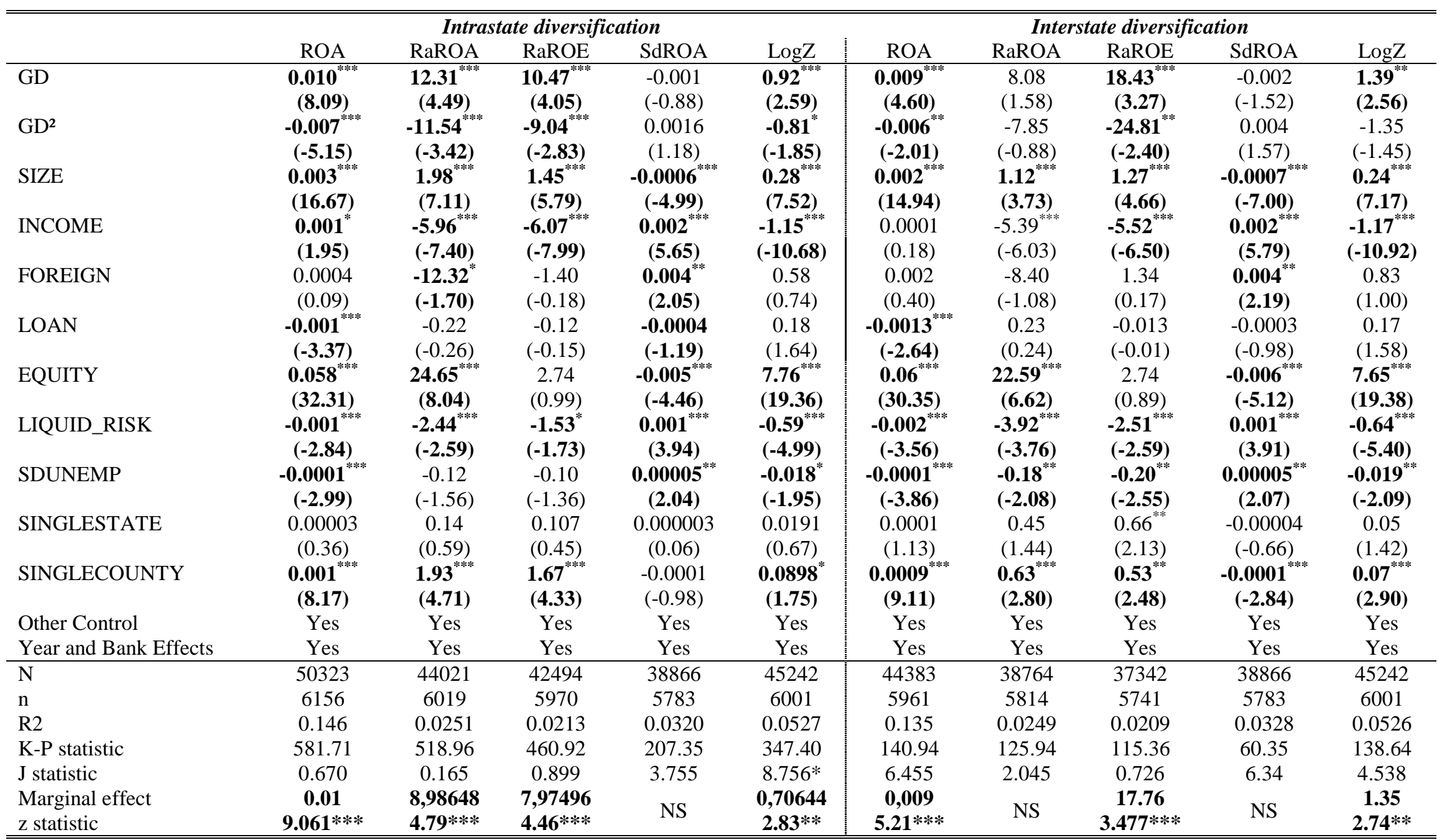


Table6: Geographic diversification and bank size

This table reports the IV regression results of our baseline model across three sub-samples of bank size (small banks (TA $\leq \$ 1 \mathrm{~B})$; large banks $(\$ 1 \mathrm{~B}<\mathrm{TA}<\$ 10 \mathrm{~B})$ andvery large banks $(\mathrm{TA} \geq \$ 10 \mathrm{~B})$ ) using GD1 and GD2 respectively as measure of geographic diversification (GEODIV) from 1994 (Interstate Banking Act) to 2006 (before the global financial crisis of 2007-2008). Explained variables are ROA, RaROA, RaROE, SdROA and logZ. GD: measures of intrastate diversification or interstate diversification.Other control: other control variables presented in section 3.4. N: number of observations; $\mathrm{n}$ : number of banks.Marginal effect: the marginal effect is calculated as the first derivative of the explained variable with respect to the geographic diversification index computed using the average value of the geographic diversification index.NS: not significant. R2: R squared. K-P statistic: Kleinberger-Paap rk F statistic for weak instrument; J statistics: Hansen-J statistic of overidentifying restrictions. $t$ statistics in parentheses, ${ }^{*} \mathrm{p}<0.1,{ }^{* *} \mathrm{p}<0.05,{ }^{* * *} \mathrm{p}<0.01$. All other variables are defined in Table 1.1.

Small banks $(\mathrm{TA} \leq \$ 1 \mathrm{~B})$

\begin{tabular}{|c|c|c|c|c|c|c|c|c|c|c|}
\hline & \multicolumn{5}{|c|}{ Intrastate diversification } & \multicolumn{5}{|c|}{ Interstate diversification } \\
\hline & ROA & RaROA & RaROE & SdROA & $\log Z$ & ROA & RaROA & RaROE & SdROA & $\log Z$ \\
\hline GD & $\begin{array}{l}0.01^{* * * *} \\
(7.88)\end{array}$ & $\begin{array}{c}14.64^{* * * *} \\
(4.93)\end{array}$ & $\begin{array}{c}10.09^{* * * *} \\
(3.62)\end{array}$ & $\begin{array}{l}-0.002 \\
(-1.51)\end{array}$ & $\begin{array}{l}1.22^{* * *} \\
(3.15)\end{array}$ & $\begin{array}{l}0.007^{*} \\
(1.74)\end{array}$ & $\begin{array}{l}12.08 \\
(1.42)\end{array}$ & $\begin{array}{l}13.84 \\
(1.55)\end{array}$ & $\begin{array}{l}-0.004 \\
(-1.02)\end{array}$ & $\begin{array}{c}1.17 \\
(1.30)\end{array}$ \\
\hline $\mathrm{GD}^{2}$ & $\begin{array}{c}-0.0084^{* * * *} \\
(-4.82)\end{array}$ & $\begin{array}{c}-14.57^{* * * *} \\
(-3.89)\end{array}$ & $\begin{array}{l}-8.12^{* * *} \\
(-2.30)\end{array}$ & $\begin{array}{c}\mathbf{0 . 0 0 3}^{*} \\
(\mathbf{1 . 8 5})\end{array}$ & $\begin{array}{l}-1.10^{* *} \\
(-2.26)\end{array}$ & $\begin{array}{l}0.003 \\
(0.37)\end{array}$ & $\begin{array}{l}-6.68 \\
(-0.36)\end{array}$ & $\begin{array}{c}-6.89 \\
(-0.34)\end{array}$ & $\begin{array}{l}0.006 \\
(0.68)\end{array}$ & $\begin{array}{c}-0.21 \\
(-0.11)\end{array}$ \\
\hline SIZE & $\begin{array}{c}0.003^{* * * *} \\
(16.52)\end{array}$ & $\begin{array}{l}2.20 * * * * \\
(7.59)\end{array}$ & $\begin{array}{l}1.68^{* * * *} \\
(6.32)\end{array}$ & $\begin{array}{c}-0.0007 \\
(-4.99)\end{array}$ & $\begin{array}{c}0.32^{* * * *} \\
(8.00)\end{array}$ & $\begin{array}{l}0.003^{* * *} \\
(15.09)\end{array}$ & $\begin{array}{l}1.53^{* * * *} \\
(5.01)\end{array}$ & $\begin{array}{l}1.45^{* * * *} \\
(5.03)\end{array}$ & $\begin{array}{c}-0.0008 \\
(-7.24)\end{array}$ & $\begin{array}{c}0.27^{* * * *} \\
(7.70)\end{array}$ \\
\hline INCOME & $\begin{array}{c}0.001 \\
(1.99)\end{array}$ & $\begin{array}{l}-5.86^{* * * *} \\
(-7.19)\end{array}$ & $\begin{array}{l}-5.95^{* * * *} \\
(-7.77)\end{array}$ & $\begin{array}{c}0.002^{* * * *} \\
(5.81)\end{array}$ & $\begin{array}{l}-1.17^{* * * *} \\
(-10.65)\end{array}$ & $\begin{array}{l}0.0001 \\
(0.18)\end{array}$ & $\begin{array}{l}-5.38 * * * * \\
(-5.97)\end{array}$ & $\begin{array}{l}-5.51^{* * * *} \\
(-6.44)\end{array}$ & $\begin{array}{c}\mathbf{0 . 0 0 2}^{* * * *} \\
(\mathbf{6 . 0 1})\end{array}$ & $\begin{array}{l}-1.20^{* * * *} \\
(-10.97)\end{array}$ \\
\hline FOREIGN & $\begin{array}{l}0.017 \\
(1.39)\end{array}$ & $\begin{array}{l}-17.70 \\
(-0.77)\end{array}$ & $\begin{array}{l}-5.44 \\
(-0.22)\end{array}$ & $\begin{array}{l}-0.004 \\
(-0.44)\end{array}$ & $\begin{array}{c}1.97 \\
(1.18)\end{array}$ & $\begin{array}{l}\mathbf{O . 0 2}^{*} \\
(\mathbf{1 . 7 7})\end{array}$ & $\begin{array}{l}18.69 \\
(0.76)\end{array}$ & $\begin{array}{l}18.32 \\
(0.80)\end{array}$ & $\begin{array}{l}-0.004 \\
(-0.44)\end{array}$ & $\begin{array}{c}1.95 \\
(1.18)\end{array}$ \\
\hline LOAN & $\begin{array}{c}-0.001 \\
(-3.26)\end{array}$ & $\begin{array}{l}-0.11 \\
(-0.13)\end{array}$ & $\begin{array}{l}-0.29 \\
(-0.36)\end{array}$ & $\begin{array}{c}-0.0003 \\
(-1.03)\end{array}$ & $\begin{array}{c}0.16 \\
(1.37)\end{array}$ & $\begin{array}{l}-0.001{ }^{* *} \\
(-2.49)\end{array}$ & $\begin{array}{c}0.19 \\
(0.20)\end{array}$ & $\begin{array}{l}-0.29 \\
(-0.31)\end{array}$ & $\begin{array}{c}-0.0003 \\
(-0.86)\end{array}$ & $\begin{array}{c}0.15 \\
(1.32)\end{array}$ \\
\hline EQUITY & $\begin{array}{l}\mathbf{0 . 0 6} \text { **** } \\
(31.84)\end{array}$ & $\begin{array}{c}25.51^{* * * *} \\
(8.17)\end{array}$ & $\begin{array}{c}4.12 \\
(1.46)\end{array}$ & $\begin{array}{c}-0.005^{* * * *} \\
(-4.71)\end{array}$ & $\begin{array}{l}7.98 \text { **** } \\
(19.45)\end{array}$ & $\begin{array}{l}0.06 \\
(29.96)\end{array}$ & $\begin{array}{c}24.07^{* * * *} \\
(6.95)\end{array}$ & $\begin{array}{c}4.14 \\
(1.33)\end{array}$ & $\begin{array}{c}-0.006 \\
(-5.38)\end{array}$ & $\begin{array}{l}7.84^{* * * *} \\
(19.45)\end{array}$ \\
\hline LIQUID_RISK & $\begin{array}{c}-0.001 \\
(-2.27)\end{array}$ & $\begin{array}{l}-2.25 * * \\
(-2.35)\end{array}$ & $\begin{array}{l}-1.66 * \\
(-1.84)\end{array}$ & $\begin{array}{c}0.001 \\
(3.57)\end{array}$ & $\begin{array}{l}-0.51^{* * * * *} \\
(-4.17)\end{array}$ & $\begin{array}{c}-0.001^{* * *} \\
(-2.96)\end{array}$ & $\begin{array}{l}-3.46^{* * *} \\
(-3.27)\end{array}$ & $\begin{array}{l}-2.42^{* *} \\
(-2.45)\end{array}$ & $\begin{array}{c}\mathbf{0 . 0 0 1}^{* * * *} \\
(\mathbf{3 . 4 6 )})\end{array}$ & $\begin{array}{l}-0.56{ }^{* * * *} \\
(-4.60)\end{array}$ \\
\hline SDUNEMP & $\begin{array}{c}-0.0001 \\
(-3.04)\end{array}$ & $\begin{array}{l}-0.12 \\
(-1.51)\end{array}$ & $\begin{array}{l}-0.12 \\
(-1.60)\end{array}$ & $\begin{array}{c}0.00005^{*} \\
(1.96)\end{array}$ & $\begin{array}{l}-0.02^{* * *} \\
(-1.99)\end{array}$ & $\begin{array}{c}-0.0001 \\
(-3.83)\end{array}$ & $\begin{array}{l}-0.18 \\
(-2.13)\end{array}$ & $\begin{array}{l}-0.23^{* * * *} \\
(-2.78)\end{array}$ & $\begin{array}{c}0.00005^{* * *} \\
(1.97)\end{array}$ & $\begin{array}{l}-0.02^{* * *} \\
(-2.08)\end{array}$ \\
\hline SINGLESTATE & $\begin{array}{c}0.00005 \\
(0.52)\end{array}$ & $\begin{array}{c}0.16 \\
(0.61)\end{array}$ & $\begin{array}{c}0.11 \\
(0.43)\end{array}$ & $\begin{array}{c}0.00005 \\
(0.85)\end{array}$ & $\begin{array}{l}-0.001 \\
(-0.05)\end{array}$ & $\begin{array}{r}0.0001 \\
(1.02)\end{array}$ & $\begin{array}{l}0.63^{*} \\
(1.84)\end{array}$ & $\begin{array}{l}0.65^{*} \\
(1.90)\end{array}$ & $\begin{array}{c}-0.00001 \\
(-0.17)\end{array}$ & $\begin{array}{c}0.03 \\
(0.89)\end{array}$ \\
\hline SINGLECOUNTY & $\begin{array}{c}0.001 * * * * \\
(7.94)\end{array}$ & $\begin{array}{l}2.18^{* * * *} \\
(5.02)\end{array}$ & $\begin{array}{l}1.60^{* * * *} \\
(3.93)\end{array}$ & $\begin{array}{l}-0.0001 \\
(-1.24)\end{array}$ & $\begin{array}{l}0.13 \\
(2.38)\end{array}$ & $\begin{array}{c}0.001 * * * \\
(9.61)\end{array}$ & $\begin{array}{l}0.72^{* * * *} \\
(3.12)\end{array}$ & $\begin{array}{l}0.55^{* *} \\
(2.52)\end{array}$ & $\begin{array}{c}-0.0002^{* * * *} \\
(-3.30)\end{array}$ & $\begin{array}{l}\text { 0.08 } \\
(3.39)\end{array}$ \\
\hline Other Control & Yes & Yes & Yes & Yes & Yes & Yes & Yes & Yes & Yes & Yes \\
\hline $\begin{array}{l}\text { Year and Bank } \\
\text { Effects }\end{array}$ & Yes & Yes & Yes & Yes & Yes & Yes & Yes & Yes & Yes & Yes \\
\hline $\mathrm{N}$ & 48346 & 42400 & 40880 & 37307 & 43432 & 42601 & 37299 & 35877 & 37307 & 43432 \\
\hline $\mathrm{n}$ & 5909 & 5771 & 5725 & 5534 & 5738 & 5701 & 5562 & 5484 & 5534 & 5738 \\
\hline R2 & 0.149 & 0.0256 & 0.0220 & 0.0321 & 0.0536 & 0.137 & 0.0250 & 0.0212 & 0.0331 & 0.0534 \\
\hline K-P statistic & 517.88 & 460.48 & 424.16 & 194.04 & 311.52 & 77.42 & 63.14 & 63.49 & 79.10 & 80.17 \\
\hline J statistic & 0.672 & 0.102 & 1.247 & 4.751 & $7.951 *$ & $8.958 *$ & 1.52 & 0.67 & 7.019 & 3.81 \\
\hline Marginal effect & 0,009 & 12,83 & 8,45 & NS & 0,95 & NS & NS & NS & NS & NS \\
\hline
\end{tabular}




\begin{tabular}{|c|c|c|c|c|c|c|c|c|c|c|}
\hline & \multicolumn{5}{|c|}{ Intrastate diversification } & \multicolumn{5}{|c|}{ Interstate diversification } \\
\hline & ROA & RaROA & RaROE & SdROA & $\log Z$ & ROA & RaROA & RaROE & SdROA & $\log Z$ \\
\hline \multirow[t]{2}{*}{ GD } & 0.004 & 3.07 & 18.28 & 0.003 & -1.53 & -0.0001 & $-35.92^{* * *}$ & -0.56 & 0.002 & -0.07 \\
\hline & $(1.11)$ & $(0.23)$ & $(1.30)$ & $(0.91)$ & $(-0.90)$ & $(-0.02)$ & $(-2.24)$ & $(-0.03)$ & $(0.36)$ & $(-0.04)$ \\
\hline \multirow[t]{2}{*}{$\mathrm{GD}^{2}$} & $-0.006 *$ & 0.24 & -19.89 & -0.002 & 0.67 & -0.006 & 23.91 & -12.18 & 0.002 & -0.39 \\
\hline & $(-1.71)$ & $(0.02)$ & $(-1.52)$ & $(-0.54)$ & $(0.44)$ & $(-1.15)$ & $(1.22)$ & $(-0.61)$ & $(0.36)$ & $(-0.18)$ \\
\hline \multirow[t]{2}{*}{ SIZE } & 0.0001 & 2.35 & 0.42 & 0.0005 & -0.22 & -0.00001 & $-4.277^{*}$ & -1.34 & 0.0008 & -0.30 \\
\hline & $(0.22)$ & (1.14) & $(0.24)$ & (1.17) & $(-1.10)$ & $(-0.02)$ & $(-1.82)$ & $(-0.67)$ & $(0.93)$ & $(-1.40)$ \\
\hline \multirow[t]{2}{*}{ INCOME } & 0.004 & -0.03 & $-12.16 *$ & $-0.003^{* * *}$ & -0.24 & 0.003 & -2.26 & -9.29 & -0.002 & -0.22 \\
\hline & $(1.53)$ & $(-0.00)$ & $(-1.87)$ & $(-2.17)$ & $(-0.34)$ & (1.13) & $(-0.31)$ & $(-1.33)$ & $(-1.61)$ & $(-0.31)$ \\
\hline \multirow[t]{2}{*}{ FOREIGN } & 0.001 & -5.91 & $18.71^{* * *}$ & 0.001 & -0.14 & -0.001 & -3.60 & 10.80 & 0.001 & 0.41 \\
\hline & $(0.55)$ & $(-0.65)$ & (1.97) & $(1.10)$ & $(-0.21)$ & $(-0.49)$ & $(-0.35)$ & (1.11) & $(0.80)$ & $(0.56)$ \\
\hline \multirow[t]{2}{*}{ LOAN } & -0.001 & 11.28 & 13.11 & -0.0006 & 1.34 & -0.002 & 14.34 & 10.44 & -0.0002 & 1.15 \\
\hline & $(-0.40)$ & $(1.38)$ & (1.64) & $(-0.40)$ & $(1.41)$ & $(-0.65)$ & (1.62) & $(1.24)$ & $(-0.14)$ & $(1.20)$ \\
\hline \multirow[t]{2}{*}{ EQUITY } & $0.04^{* * * *}$ & 11.32 & -22.08 & 0.006 & $4.59^{*}$ & $0.04^{* * * *}$ & 18.01 & -33.06 & 0.005 & 3.99 \\
\hline & (4.65) & $(0.49)$ & $(-1.07)$ & $(1.11)$ & (1.73) & (4.73) & $(0.79)$ & $(-1.59)$ & $(0.89)$ & (1.53) \\
\hline \multirow[t]{2}{*}{ LIQUID_RISK } & -0.003 *** & -3.25 & $10.03^{*}$ & 0.002 & $-1.71^{* * *}$ & $-0.004^{* * *}$ & $-14.00^{*}$ & 2.52 & $0.002 *$ & $-1.74^{* * *}$ \\
\hline & $(-2.13)$ & $(-0.50)$ & (1.68) & (1.64) & $(-2.56)$ & $(-2.47)$ & $(-1.95)$ & $(0.40)$ & (1.81) & $(-2.56)$ \\
\hline \multirow[t]{2}{*}{ SDUNEMP } & -0.0002 & 0.51 & 0.41 & 0.0001 & -0.02 & -0.0001 & 0.36 & 0.57 & 0.0002 & -0.02 \\
\hline & $(-1.38)$ & $(0.69)$ & $(0.65)$ & (1.29) & $(-0.24)$ & $(-0.93)$ & $(0.41)$ & $(0.83)$ & (1.16) & $(-0.25)$ \\
\hline \multirow[t]{2}{*}{ SINGLESTATE } & -0.0001 & 0.29 & 0.38 & $-0.0003^{* * *}$ & 0.13 & 0.0001 & $0.63^{*}$ & $0.60^{*}$ & $-0.0003^{* *}$ & $0.15^{*}$ \\
\hline & $(-0.65)$ & $(0.39)$ & $(0.53)$ & $(-2.32)$ & $(1.61)$ & $(1.02)$ & (1.84) & (1.90) & $(-2.47)$ & (1.72) \\
\hline \multirow[t]{2}{*}{ SINGLECOUNTY } & -0.0003 & -1.14 & 1.98 & 0.0003 & -0.10 & $0.001^{* * * *}$ & $0.72^{* * * *}$ & $0.55^{* *}$ & 0.0003 & -0.05 \\
\hline & $(-0.64)$ & $(-0.71)$ & $(1.05)$ & $(0.91)$ & $(-0.51)$ & $(9.61)$ & (3.12) & $(2.52)$ & $(1.28)$ & $(-0.31)$ \\
\hline Other Control & Yes & Yes & Yes & Yes & Yes & Yes & Yes & Yes & Yes & Yes \\
\hline \multicolumn{11}{|l|}{ Effects } \\
\hline $\mathrm{N}$ & 1773 & 1426 & 1425 & 1402 & 1620 & 1596 & 1291 & 1293 & 1402 & 1620 \\
\hline $\mathrm{n}$ & 327 & 302 & 296 & 291 & 318 & 312 & 290 & 285 & 291 & 318 \\
\hline $\mathrm{r} 2$ & 0.085 & 0.028 & 0.030 & 0.055 & 0.041 & 0.078 & 0.023 & 0.038 & 0.05 & 0.041 \\
\hline K-P statistic & 38.47 & 28.10 & 31.32 & 22.50 & 23.51 & 11.80 & 9.97 & 8.95 & 11.05 & 11.50 \\
\hline J statistic & 1.130 & 2.950 & 0.411 & 1.485 & 1.488 & 4.039 & $7.95^{*}$ & 2.38 & 5.007 & 3.082 \\
\hline Marginal effect & NS & NS & NS & NS & NS & NS & NS & NS & NS & NS \\
\hline
\end{tabular}


Very large banks $(\mathrm{TA} \geq \$ 10 \mathrm{~B})$

\begin{tabular}{|c|c|c|c|c|c|c|c|c|c|c|}
\hline & \multicolumn{5}{|c|}{ Intrastate diversification } & \multicolumn{5}{|c|}{ Interstate diversification } \\
\hline & ROA & RaROA & RaROE & SdROA & $\log Z$ & ROA & RaROA & RaROE & SdROA & $\log Z$ \\
\hline \multirow[t]{2}{*}{ GD } & 0.039 & $147.50^{*}$ & 140.60 & -0.01 & 13.24 & 0.0007 & 44.84 & 45.54 & -0.01 & $9.25^{* * *}$ \\
\hline & $(1.34)$ & (1.74) & $(1.51)$ & $(-1.00)$ & $(1.40)$ & $(0.05)$ & $(0.88)$ & $(0.87)$ & $(-1.33)$ & (1.99) \\
\hline \multirow[t]{2}{*}{$\mathrm{GD}^{2}$} & -0.009 & -96.71 & -118.10 & $0.020 *$ & -10.23 & 0.005 & -25.24 & -38.78 & 0.009 & $-7.80 *$ \\
\hline & $(-0.42)$ & $(-1.45)$ & $(-1.63)$ & (1.71) & $(-1.48)$ & $(0.41)$ & $(-0.53)$ & $(-0.87)$ & $(1.53)$ & $(-2.03)$ \\
\hline \multirow[t]{2}{*}{ SIZE } & 0.0008 & $17.02^{* * * *}$ & 10.62 & $-0.00195^{*}$ & $1.94^{* * * *}$ & 0.001 & $9.22^{* * *}$ & $9.678^{* *}$ & -0.0009 & $0.89^{* *}$ \\
\hline & $(0.41)$ & $(2.75)$ & $(1.31)$ & $(-1.79)$ & (2.99) & $(0.75)$ & (2.12) & $(2.06)$ & $(-1.34)$ & (1.98) \\
\hline \multirow[t]{2}{*}{ INCOME } & 0.027 & 1.65 & 44.78 & -0.0026 & 1.52 & 0.01 & 67.76 & 79.75 & -0.01 & $9.63^{* * *}$ \\
\hline & $(1.61)$ & $(0.03)$ & $(0.68)$ & $(-0.31)$ & $(0.29)$ & $(0.80)$ & $(1.51)$ & $(1.62)$ & $(-1.33)$ & (2.13) \\
\hline \multirow[t]{2}{*}{ FOREIGN } & $0.029^{* * *}$ & -56.80 & -13.58 & $0.018^{* * *}$ & -7.07 & 0.007 & -41.27 & -17.11 & $0.0075^{*}$ & -2.07 \\
\hline & (2.11) & $(-1.40)$ & $(-0.30)$ & $(2.52)$ & $(-1.64)$ & $(0.78)$ & $(-1.52)$ & $(-0.59)$ & (1.69) & $(-0.77)$ \\
\hline \multirow[t]{2}{*}{ LOAN } & 0.005 & $60.80^{* *}$ & $80.06 * *$ & $-0.011^{* *}$ & $6.49^{* *}$ & -0.006 & $46.04^{*}$ & 38.80 & $-0.009^{* *}$ & $7.78^{* * * *}$ \\
\hline & $(0.56)$ & $(2.01)$ & (2.39) & $(-2.20)$ & (2.17) & $(-0.69)$ & (1.65) & $(1.23)$ & $(-2.01)$ & (3.03) \\
\hline \multirow[t]{2}{*}{ EQUITY } & 0.02 & -3.77 & $-223.60^{* *}$ & 0.008 & -9.38 & $0.05^{* *}$ & -11.78 & $-166.30 *$ & 0.009 & -3.41 \\
\hline & $(0.98)$ & $(-0.05)$ & $(-2.38)$ & $(0.59)$ & $(-1.13)$ & (1.98) & $(-0.15)$ & $(-1.83)$ & $(0.76)$ & $(-0.46)$ \\
\hline \multirow[t]{2}{*}{ LIQUID_RISK } & -0.005 & 30.68 & 32.13 & $-0.007^{*}$ & $4.00 *$ & 0.003 & 10.56 & 28.82 & -0.003 & $2.86 *$ \\
\hline & $(-0.74)$ & $(1.19)$ & $(1.21)$ & $(-1.70)$ & (1.67) & $(0.56)$ & $(0.61)$ & $(1.49)$ & $(-1.04)$ & (1.67) \\
\hline \multirow[t]{2}{*}{ SDUNEMP } & 0.0003 & 1.92 & 1.81 & -0.00006 & 0.11 & 0.0003 & 2.00 & 2.47 & 0.00002 & -0.02 \\
\hline & $(0.57)$ & (1.33) & $(0.99)$ & $(-0.25)$ & $(0.72)$ & $(0.75)$ & $(1.29)$ & $(1.55)$ & $(0.12)$ & $(-0.23)$ \\
\hline \multirow[t]{2}{*}{ SINGLESTATE } & 0.0007 & $10.45^{* * *}$ & 5.72 & $-0.001^{* * *}$ & $1.02^{* * * *}$ & 0.001 & 6.41 & 5.10 & $-0.002^{* * *}$ & $1.60^{* * * *}$ \\
\hline & $(0.18)$ & $(2.84)$ & (1.34) & $(-2.90)$ & (3.05) & $(1.22)$ & (1.07) & $(0.97)$ & $(-2.22)$ & (3.09) \\
\hline SINGLECOUNTY & - & - & - & - & - & - & - & - & - & - \\
\hline Other Controls & Yes & Yes & Yes & Yes & Yes & Yes & Yes & Yes & Yes & Yes \\
\hline $\begin{array}{l}\text { Year and Bank } \\
\text { Effects }\end{array}$ & Yes & Yes & Yes & Yes & Yes & Yes & Yes & Yes & Yes & Yes \\
\hline $\mathrm{N}$ & 107 & 98 & 90 & 128 & 130 & 130 & 115 & 111 & 128 & 130 \\
\hline $\mathrm{n}$ & 23 & 22 & 22 & 23 & 23 & 23 & 22 & 22 & 23 & 23 \\
\hline $\mathrm{r} 2$ & 0.465 & 0.442 & 0.459 & 0.449 & 0.440 & 0.363 & 0.355 & 0.371 & 0.407 & 0.395 \\
\hline K-P statistic & 6.53 & 6.26 & 5.25 & 6.14 & 6.46 & 21.356 & 13.97 & 17.08 & 20.33 & 21.35 \\
\hline J statistic & 6.56 & 7.16 & 3.74 & $13.18 * *$ & $10.01 *$ & 2.75 & 4.29 & 8.14 & 0.87 & 2.45 \\
\hline Marginal effect & NS & NS & NS & NS & NS & NS & NS & NS & NS & 0.24 \\
\hline z statistic & & & & & & & & & & $1.97 * *$ \\
\hline
\end{tabular}




\section{Appendix}

Table A1: Effect of Geographic Diversification on Bank Risk and Performance - Crisis period (2007-2008)

This table reports the OLS regression results of our baseline model using GD1 and GD2 respectively as measure of geographic diversification (GD) over the crisis period (20072008). Explained variables are ROA, RaROA, RaROE, SdROA and logZ. GD: measures of intrastate diversification or interstate diversification. Other control: other control variables presented in section 3.4. N: number of observations; n: number of banks. The marginal effect is calculated as the first derivative of the explained variable with respect to the geographic diversification index computed using the average value of the geographic diversification index. NS: not significant. K-P statistic: Kleinberger-Paap rk F statistic for weak instrument; J statistics: Hansen-J statistic of overidentifying restrictions. $\mathrm{t}$ statistics in parentheses, $* \mathrm{p}<0.1, * * \mathrm{p}<0.05, * * * \mathrm{p}<0.01$. All other variables are defined in Table 1.1. All models include bank and year effects.

\begin{tabular}{|c|c|c|c|c|c|c|c|c|c|c|}
\hline & \multicolumn{5}{|c|}{ Intrastate diversification } & \multicolumn{5}{|c|}{ Interstate diversification } \\
\hline & ROA & RaROA & RaROE & SdROA & $\log Z$ & ROA & RaROA & RaROE & SdROA & $\log Z$ \\
\hline \multirow[t]{2}{*}{ GD } & 0.005 & 10.68 & 6.61 & $-0.006^{*}$ & $2.73^{* * *}$ & -0.006 & -34.10 & 4.51 & 0.001 & -1.69 \\
\hline & $(0.88)$ & $(1.16)$ & $(0.69)$ & $(-1.71)$ & $(2.47)$ & $(-0.51)$ & $(-1.44)$ & $(0.17)$ & $(0.22)$ & $(-0.87)$ \\
\hline \multirow[t]{2}{*}{$\mathrm{GD}^{2}$} & -0.006 & $-24.07^{*}$ & -16.39 & 0.006 & -2.19 & 0.004 & 41.27 & -37.54 & -0.007 & 5.66 \\
\hline & $(-0.67)$ & $(-1.75)$ & $(-1.18)$ & $(1.20)$ & $(-1.47)$ & $(0.19)$ & $(0.81)$ & $(-0.53)$ & $(-0.52)$ & $(1.58)$ \\
\hline \multirow[t]{2}{*}{ SIZE } & 0.001 & $-5.14^{* *}$ & -2.69 & $-0.001^{*}$ & $0.61^{* * *}$ & 0.001 & $-5.04^{* *}$ & -2.46 & $-0.0011^{*}$ & $0.61^{* * *}$ \\
\hline & $(0.91)$ & $(-2.37)$ & $(-1.34)$ & $(-1.93)$ & $(2.42)$ & $(0.99)$ & $(-2.43)$ & $(-1.26)$ & $(-1.89)$ & $(2.46)$ \\
\hline \multirow[t]{2}{*}{ INCOME } & -0.003 & $-7.90 *$ & $-9.95^{* * *}$ & $0.003^{* * *}$ & -0.25 & -0.003 & $-7.33^{*}$ & $-9.68^{* *}$ & $\mathrm{0.003}^{* *}$ & -0.25 \\
\hline & $(-1.10)$ & $(-1.91)$ & $(-2.61)$ & $(2.41)$ & $(-0.63)$ & $(-1.07)$ & $(-1.78)$ & $(-2.53)$ & (2.37) & $(-0.65)$ \\
\hline \multirow[t]{2}{*}{ FOREIGN } & $-0.04^{*}$ & 90.74 & $-84.38^{* * * *}$ & $0.03^{* *}$ & -0.96 & $-0.03^{*}$ & $122.7^{* *}$ & -123.0 & 0.02 & 0.78 \\
\hline & $(-1.93)$ & $(1.44)$ & $(-3.02)$ & $(2.22)$ & $(-0.30)$ & $(-1.87)$ & $(2.53)$ & $(-1.23)$ & $(1.50)$ & $(0.38)$ \\
\hline \multirow[t]{2}{*}{ LOAN } & 0.002 & 0.31 & -5.60 & -0.001 & 0.12 & 0.002 & 0.64 & -5.47 & -0.002 & 0.12 \\
\hline & $(0.64)$ & $(0.06)$ & $(-1.09)$ & $(-0.98)$ & $(0.19)$ & $(0.60)$ & $(0.12)$ & $(-1.06)$ & $(-0.95)$ & $(0.19)$ \\
\hline \multirow[t]{2}{*}{ SDUNEMP } & $-0.002^{* * *}$ & $-1.81^{* * * *}$ & $-1.77^{* * *}$ & $0.001^{* * * *}$ & $-0.44^{* * *}$ & $-0.002^{* * *}$ & $-1.78^{* * *}$ & $-1.76^{* * * *}$ & $0.001^{* * *}$ & $-0.44^{* * *}$ \\
\hline & $(-10.96)$ & $(-4.75)$ & $(-4.70)$ & (10.11) & $(-10.70)$ & $(-11.00)$ & $(-4.70)$ & $(-4.75)$ & $(10.06)$ & $(-10.69)$ \\
\hline \multirow[t]{2}{*}{ EQUITY } & $0.09^{* * *}$ & $29.99^{*}$ & 25.30 & $-0.04^{* * * *}$ & $21.54^{* * * *}$ & $0.09^{* * *}$ & $30.75^{*}$ & 26.44 & $-0.04^{* * * *}$ & $21.45^{* * *}$ \\
\hline & $(6.64)$ & (1.68) & $(1.46)$ & $(-4.76)$ & (7.99) & $(6.66)$ & (1.73) & $(1.57)$ & $(-4.75)$ & (7.98) \\
\hline \multirow[t]{2}{*}{ LIQUID_RISK } & -0.001 & 1.81 & 1.92 & $0.002^{*}$ & -0.33 & -0.001 & 1.92 & 2.07 & $0.003^{*}$ & -0.32 \\
\hline & $(-0.63)$ & $(0.45)$ & $(0.46)$ & (1.74) & $(-0.81)$ & $(-0.56)$ & $(0.48)$ & $(0.50)$ & (1.72) & $(-0.79)$ \\
\hline \multirow[t]{2}{*}{ SINGLECOUNTY } & 0.0001 & $2.35^{*}$ & 1.40 & 0.0001 & 0.11 & -0.00003 & 0.32 & 0.49 & 0.0003 & 0.01 \\
\hline & $(0.21)$ & (1.87) & $(1.16)$ & $(0.34)$ & $(0.79)$ & $(-0.06)$ & $(0.31)$ & $(0.53)$ & $(0.81)$ & $(0.08)$ \\
\hline \multirow[t]{2}{*}{ SINGLESTATE } & $-0.0006 *$ & 0.26 & 0.18 & 0.00008 & 0.01 & $-0.0007^{* *}$ & 0.33 & 0.34 & 0.0001 & 0.001 \\
\hline & $(-1.90)$ & $(0.37)$ & $(0.24)$ & $(0.40)$ & $(0.14)$ & $(-2.08)$ & $(0.47)$ & $(0.44)$ & $(0.48)$ & $(0.02)$ \\
\hline \multirow[t]{2}{*}{ Constant } & 0.00559 & 8.932 & $14.62^{* *}$ & $0.00467^{*}$ & $2.302^{* * * *}$ & 0.00611 & 9.540 & $14.50^{* * * *}$ & $0.00405^{*}$ & $2.614^{* * *}$ \\
\hline & (1.39) & $(1.46)$ & $(2.53)$ & (1.89) & (3.41) & (1.61) & $(1.63)$ & $(2.63)$ & (1.75) & (4.11) \\
\hline Other control & Yes & Yes & Yes & Yes & Yes & Yes & Yes & Yes & Yes & Yes \\
\hline Year and Bank Effects & Yes & Yes & Yes & Yes & Yes & Yes & Yes & Yes & Yes & Yes \\
\hline $\mathrm{N}$ & 7935 & 6514 & 6262 & 7928 & 8161 & 7935 & 6514 & 6262 & 7928 & 8161 \\
\hline $\mathrm{n}$ & 4266 & 3893 & 3794 & 4232 & 4283 & 4266 & 3893 & 3794 & 4232 & 4283 \\
\hline $\mathrm{R} 2$ & 0.332 & 0.0754 & 0.0716 & 0.134 & 0.158 & 0.332 & 0.0739 & 0.0714 & 0.134 & 0.158 \\
\hline
\end{tabular}


Table A2: Geographic diversification and bank size - Crisis period (2007-2008)

This table reports the OLS regression results of our baseline model across three sub-samples of bank size (small banks $(\mathrm{TA} \leq \$ 1 \mathrm{~B})$; large banks $(\$ 1 \mathrm{~B}<\mathrm{TA}<\$ 10 \mathrm{~B})$ and very large banks (TA $\geq \$ 10 B)$ ) using GD1 and GD2 respectively as measure of geographic diversification (GEODIV) over the crisis period (2007-2008). Explained variables are ROA, RaROA, RaROE, SdROA and logZ. GD: measures of intrastate diversification or interstate diversification. Other control: other control variables presented in section 3.4. N: number of observations; $\mathrm{n}$ : number of banks. Marginal effect: the marginal effect is calculated as the first derivative of the explained variable with respect to the geographic diversification index computed using the average value of the geographic diversification index. NS: not significant. R2: R squared. K-P statistic: Kleinberger-Paap rk F statistic for weak instrument; J statistics: Hansen-J statistic of overidentifying restrictions.t statistics in parentheses, $* \mathrm{p}<0.1, * * \mathrm{p}<0.05$, $* * * \mathrm{p}<0.01$. All other variables are defined in Table 1.1 .

Small banks $(\mathrm{TA} \leq \$ 1 \mathrm{~B})$

\begin{tabular}{|c|c|c|c|c|c|c|c|c|c|c|}
\hline & \multicolumn{5}{|c|}{ Intrastate diversification } & \multicolumn{5}{|c|}{ Interstate diversification } \\
\hline & ROA & RaROA & RaROE & SdROA & $\log Z$ & ROA & RaROA & RaROE & SdROA & $\log Z$ \\
\hline \multirow[t]{2}{*}{ GD } & 0.01 & 7.48 & 5.42 & -0.008 8* & $3.25^{* * * *}$ & -0.014 & -36.83 & -31.26 & 0.009 & -2.69 \\
\hline & (1.44) & $(0.81)$ & $(0.57)$ & $(-2.10)$ & (2.64) & $(-0.90)$ & $(-1.31)$ & $(-1.15)$ & $(1.16)$ & $(-1.19)$ \\
\hline \multirow[t]{2}{*}{$\mathrm{GD}^{2}$} & -0.008 & -14.56 & -9.04 & 0.006 & -2.31 & 0.042 & 84.23 & 92.66 & $-0.041^{* * *}$ & $13.82^{\text {**** }}$ \\
\hline & $(-0.78)$ & $(-1.07)$ & $(-0.62)$ & $(1.28)$ & $(-1.38)$ & $(1.28)$ & $(1.36)$ & (1.44) & $(-2.38)$ & (3.10) \\
\hline \multirow[t]{2}{*}{ SIZE } & $0.003^{* *}$ & $-4.07^{*}$ & -1.77 & $-0.003^{\text {**** }}$ & $0.93^{* * *}$ & $\mathrm{0.0033}^{* *}$ & $-3.65^{*}$ & -1.69 & $-0.002^{2 *}$ & $0.89^{* * * *}$ \\
\hline & (2.30) & $(-1.93)$ & $(-0.88)$ & $(-2.64)$ & (3.30) & (2.31) & $(-1.75)$ & $(-0.85)$ & $(-2.52)$ & (3.19) \\
\hline \multirow[t]{2}{*}{ INCOME } & -0.003 & $-8.08^{*}$ & $-10.89^{* * * *}$ & $0.003^{* *}$ & -0.38 & -0.0032 & $-7.82^{*}$ & $-10.95^{* * * *}$ & $0.003^{* *}$ & -0.40 \\
\hline & $(-1.01)$ & $(-1.96)$ & $(-2.85)$ & $(2.44)$ & $(-0.94)$ & $(-1.01)$ & $(-1.90)$ & $(-2.85)$ & $(2.47)$ & $(-1.00)$ \\
\hline \multirow[t]{2}{*}{ FOREIGN } & $0.16^{* * * *}$ & 533.6 **** & $548.1^{* * * *}$ & $-0.04^{* * * *}$ & $18.59^{* * * *}$ & $0.16^{* * *}$ & $508.9^{* * * *}$ & $556.9^{* * * *}$ & $-0.04^{* * * *}$ & $18.51^{* * * *}$ \\
\hline & (11.53) & $(5.89)$ & $(\mathbf{5 . 8 0})$ & $(-4.35)$ & (4.71) & $(10.92)$ & (4.45) & & $(-4.46)$ & $(\mathbf{4 . 8 4})$ \\
\hline \multirow[t]{2}{*}{ LOAN } & 0.002 & -0.83 & -5.48 & -0.003 & 0.22 & 0.002 & -0.46 & -5.52 & -0.003 & 0.22 \\
\hline & $(0.60)$ & $(-0.15)$ & $(-1.08)$ & $(-1.46)$ & $(0.34)$ & $(0.57)$ & $(-0.08)$ & $(-1.09)$ & $(-1.42)$ & $(0.35)$ \\
\hline \multirow[t]{2}{*}{ SDUNEMP } & $-0.002^{* * *}$ & $-1.70^{* * * *}$ & $-1.75^{* * * *}$ & $0.001^{* * * *}$ & $-0.43^{* * * *}$ & $-0.002^{* * * *}$ & $-1.70^{* * * *}$ & $-1.75^{* * * *}$ & $0.001^{* * * * *}$ & $-0.43^{* * *}$ \\
\hline & $(-10.85)$ & $(-4.53)$ & $(-4.67)$ & $(9.48)$ & $(-10.28)$ & $(-10.88)$ & $(-4.54)$ & $(-4.68)$ & $(9.44)$ & $(-10.22)$ \\
\hline \multirow[t]{2}{*}{ EQUITY } & $0.11^{* * * *}$ & $42.18^{* * *}$ & $29.86^{*}$ & $-0.05^{* * *}$ & $22.28^{* * * *}$ & $0.11^{* * *}$ & $44.32^{* *}$ & $30.61^{*}$ & $-0.05^{* * * *}$ & $22.08^{* * * *}$ \\
\hline & $(6.75)$ & $(\mathbf{2 . 3 3})$ & (1.74) & $(-4.77)$ & $(\mathbf{7 . 5 3})$ & $(6.74)$ & $(2.46)$ & & & $(7.50)$ \\
\hline \multirow[t]{2}{*}{ LIQUID_RISK } & 0.00006 & 0.32 & 0.46 & 0.002 & -0.34 & 0.00008 & 0.14 & 0.072 & 0.002 & -0.37 \\
\hline & $(0.03)$ & $(0.08)$ & $(0.11)$ & $(1.23)$ & $(-0.83)$ & $(0.03)$ & $(0.03)$ & $(0.02)$ & & $(-0.89)$ \\
\hline \multirow[t]{2}{*}{ SINGLECOUNTY } & 0.00008 & 1.77 & 1.05 & 0.0002 & 0.071 & -0.00005 & 0.10 & 0.19 & 0.0003 & -0.02 \\
\hline & & $(1.42)$ & $(0.97)$ & $(0.42)$ & $(0.46)$ & $(-0.08)$ & $(0.10)$ & $(0.22)$ & $(0.86)$ & $(-0.18)$ \\
\hline \multirow[t]{2}{*}{ SINGLESTATE } & -0.0005 & 0.49 & 0.80 & -0.00002 & 0.11 & -0.0006 & 0.48 & 0.78 & 0.00002 & 0.09 \\
\hline & $(-1.31)$ & $(0.68)$ & & $(-0.09)$ & & $(-1.55)$ & $(0.66)$ & $(1.06)$ & $(0.12)$ & $(1.25)$ \\
\hline \multirow[t]{2}{*}{ Constant } & 0.00197 & 7.437 & $13.55^{* *}$ & $0.00661^{* *}$ & $2.122^{* * * *}$ & 0.00315 & 8.205 & $14.46^{* * * *}$ & $0.00554^{* *}$ & $2.514^{* * * *}$ \\
\hline & $(0.47)$ & $(1.24)$ & $(\mathbf{2 . 3 5})$ & & & & $(1.42)$ & & & \\
\hline Other control & Yes & Yes & Yes & Yes & Yes & Yes & Yes & Yes & Yes & Yes \\
\hline Year and Bank Effects & Yes & Yes & Yes & Yes & Yes & Yes & Yes & Yes & Yes & Yes \\
\hline $\mathrm{N}$ & 7462 & 6154 & 5912 & 7468 & 7669 & 7462 & 6154 & 5912 & 7468 & 7669 \\
\hline $\mathrm{n}$ & 3996 & 3663 & 3561 & 3973 & 4016 & 3996 & 3663 & 3561 & 3973 & 4016 \\
\hline R2 & 0.318 & 0.0625 & 0.0613 & 0.135 & 0.153 & 0.319 & 0.0618 & 0.0618 & 0.136 & 0.154 \\
\hline
\end{tabular}


Large banks $(\$ 1 \mathrm{~B}<\mathrm{TA}<\$ 10 \mathrm{~B})$

\begin{tabular}{|c|c|c|c|c|c|c|c|c|c|c|}
\hline & \multicolumn{5}{|c|}{ Intrastate diversification } & \multicolumn{5}{|c|}{ Interstate diversification } \\
\hline & ROA & RaROA & RaROE & SdROA & $\log Z$ & ROA & RaROA & RaROE & SdROA & $\log Z$ \\
\hline \multirow[t]{2}{*}{ GD } & -0.006 & -64.14 & $-97.51^{* * 2}$ & -0.003 & -2.29 & -0.03 & -59.08 & -42.22 & -0.006 & -3.08 \\
\hline & $(-0.23)$ & $(-1.06)$ & $(-2.01)$ & $(-0.20)$ & $(-0.43)$ & $(-1.43)$ & $(-1.03)$ & $(-1.13)$ & $(-0.55)$ & $(-0.64)$ \\
\hline \multirow[t]{2}{*}{$\mathrm{GD}^{2}$} & 0.003 & 6.67 & 32.21 & 0.008 & -2.67 & -0.01 & -39.83 & $-76.81^{*}$ & 0.024 & -2.94 \\
\hline & $(0.12)$ & $(0.14)$ & $(0.69)$ & $(0.43)$ & $(-0.51)$ & $(-0.42)$ & $(-0.78)$ & $(-1.94)$ & $(1.48)$ & $(-0.53)$ \\
\hline \multirow[t]{2}{*}{ SIZE } & $-0.009^{* * *}$ & -17.67 & -7.17 & $0.005^{* * * *}$ & $-2.93^{* * * *}$ & $-0.008^{*}$ & -14.44 & -2.47 & $0.006^{* * * *}$ & $-3.17^{* * * *}$ \\
\hline & $(-2.41)$ & $(-1.41)$ & $(-0.79)$ & $(2.60)$ & $(-3.66)$ & $(-1.91)$ & $(-1.15)$ & $(-0.28)$ & $(2.71)$ & $(-3.71)$ \\
\hline \multirow[t]{2}{*}{ INCOME } & -0.01 & -28.03 & -18.94 & -0.001 & 1.64 & -0.01 & -31.10 & -23.12 & -0.0004 & 1.43 \\
\hline & $(-1.38)$ & $(-0.86)$ & $(-0.80)$ & $(-0.12)$ & $(0.68)$ & $(-1.26)$ & $(-0.98)$ & $(-0.94)$ & $(-0.04)$ & $(0.59)$ \\
\hline \multirow[t]{2}{*}{ FOREIGN } & -0.09 & -36.43 & 166.1 & $0.11^{* * * *}$ & 7.30 & $-0.17^{* * * *}$ & -253.0 & -214.2 & $0.11^{* * * *}$ & 6.50 \\
\hline & $(-1.59)$ & $(-0.14)$ & $(0.86)$ & $(2.74)$ & (1.64) & $(-4.00)$ & $(-0.91)$ & $(-1.03)$ & (3.74) & $(1.65)$ \\
\hline \multirow[t]{2}{*}{ LOAN } & 0.006 & -7.04 & -48.62 & 0.03 & -4.42 & 0.002 & 1.41 & -38.55 & 0.03 & -4.19 \\
\hline & $(0.38)$ & $(-0.12)$ & $(-0.90)$ & $(1.49)$ & $(-1.08)$ & $(0.16)$ & $(0.02)$ & $(-0.71)$ & $(1.45)$ & $(-1.01)$ \\
\hline \multirow[t]{2}{*}{ SDUNEMP } & -0.001 & -1.43 & 0.62 & $0.002^{* * * *}$ & $-0.60^{* * * *}$ & -0.001 & -2.03 & -0.80 & $0.002^{* * *}$ & $-0.56^{* * *}$ \\
\hline & $(-1.20)$ & $(-0.57)$ & $(0.31)$ & (3.13) & $(-2.74)$ & $(-1.46)$ & $(-0.82)$ & $(-0.43)$ & $(2.83)$ & $(-2.53)$ \\
\hline \multirow[t]{2}{*}{ EQUITY } & -0.02 & -52.36 & -11.38 & -0.02 & $18.02^{* * * *}$ & -0.02 & -43.88 & 22.40 & -0.02 & $17.57^{* * * *}$ \\
\hline & $(-0.80)$ & $(-0.87)$ & $(-0.12)$ & $(-1.13)$ & $(3.44)$ & $(-0.53)$ & $(-0.73)$ & $(0.26)$ & $(-1.20)$ & (3.55) \\
\hline \multirow[t]{2}{*}{ LIQUID_RISK } & 0.0002 & $51.46^{* * *}$ & $33.75^{* *}$ & 0.005 & 1.43 & -0.0009 & $50.26^{* * * *}$ & $34.84^{* *}$ & 0.006 & 1.49 \\
\hline & $(0.03)$ & $(2.58)$ & $(2.46)$ & $(0.92)$ & $(0.84)$ & $(-0.13)$ & $(2.63)$ & $(2.58)$ & $(0.93)$ & $(0.87)$ \\
\hline \multirow[t]{2}{*}{ SINGLECOUNTY } & 0.0009 & $11.50^{* * * *}$ & 9.74 & -0.0008 & $0.78^{*}$ & 0.001 & $10.57^{* * * *}$ & 8.60 & -0.0006 & $0.75^{*}$ \\
\hline & $(0.67)$ & $(3.52)$ & $(1.03)$ & $(-0.74)$ & (1.94) & $(0.77)$ & (3.07) & $(0.93)$ & $(-0.62)$ & (1.87) \\
\hline \multirow[t]{2}{*}{ SINGLESTATE } & $-0.001^{* *}$ & -2.29 & $-4.10^{*}$ & 0.0008 & $-0.58^{* * * *}$ & $-0.001^{* * * *}$ & -1.99 & -3.75 & 0.0007 & $-0.55^{* * * *}$ \\
\hline & $(-2.55)$ & $(-1.00)$ & $(-1.89)$ & $(1.31)$ & $(-2.85)$ & $(-3.03)$ & $(-0.81)$ & $(-1.62)$ & $(1.16)$ & $(-2.73)$ \\
\hline \multirow[t]{2}{*}{ Constant } & $0.0447^{* * *}$ & 82.80 & 90.27 & $-0.0431^{* *}$ & $14.95^{* * * *}$ & $0.0505^{* * * *}$ & 57.85 & 47.11 & $-0.0453^{* *}$ & $15.02^{* * * *}$ \\
\hline & $(2.26)$ & $(1.10)$ & $(1.56)$ & $(-2.32)$ & (3.30) & $(2.74)$ & $(0.83)$ & $(0.87)$ & $(-2.49)$ & (3.64) \\
\hline Other control & Yes & Yes & Yes & Yes & Yes & Yes & Yes & Yes & Yes & Yes \\
\hline Year and Bank Effects & Yes & Yes & Yes & Yes & Yes & Yes & Yes & Yes & Yes & Yes \\
\hline $\mathrm{N}$ & 453 & 343 & 336 & 438 & 470 & 453 & 343 & 336 & 438 & 470 \\
\hline $\mathrm{n}$ & 268 & 226 & 224 & 257 & 267 & 268 & 226 & 224 & 257 & 267 \\
\hline $\mathrm{R} 2$ & 0.658 & 0.415 & 0.417 & 0.273 & 0.366 & 0.657 & 0.422 & 0.430 & 0.275 & 0.369 \\
\hline
\end{tabular}


Table A3: Effect of Geographic Diversification on Bank Risk and Performance - Alternative measure of intrastate diversification

This table reports the IV regression results of our baseline model using an alternative measure of intrastate diversification that counts individual MSAs separately but treats nonMSA counties as a single entity from 1994 (Interstate Banking Act) to 2006(before the global financial crisis of 2007-2008). Explained variables are ROA, RaROA, RaROE, SdROA and logZ. GD: measures of intrastate diversification. Other control: other control variables presented in section 3.4. N: number of observations; n: number of banks. The marginal effect is calculated as the first derivative of the explained variable with respect to the geographic diversification index computed using the average value of the geographic diversification index. NS: not significant. K-P statistic: Kleinberger-Paap rk F statistic for weak instrument; J statistics: Hansen-J statistic of overidentifying restrictions. $\mathrm{t}$ statistics in parentheses, $* \mathrm{p}<0.1, * * \mathrm{p}<0.05, * * * \mathrm{p}<0.01$. All other variables are defined in Table 1.1. All models include bank and year effects.

\begin{tabular}{|c|c|c|c|c|c|}
\hline & ROA & RaROA & RaROE & SdROA & $\log Z$ \\
\hline GD & $\begin{array}{c}\mathbf{0 . 0 0 8}^{* * * *} \\
(\mathbf{8 . 0 8})\end{array}$ & $\begin{array}{l}6.61^{* * *} \\
(2.66)\end{array}$ & $\begin{array}{l}9.28 \text { **** } \\
(3.93)\end{array}$ & $\begin{array}{c}-0.002^{* * *} \\
(-3.39)\end{array}$ & $\begin{array}{l}0.81^{* * * *} \\
(2.59)\end{array}$ \\
\hline $\mathrm{GD}^{2}$ & $\begin{array}{c}-0.007^{* * * *} \\
(-4.50)\end{array}$ & $\begin{array}{l}-7.26^{*} \\
(-1.90)\end{array}$ & $\begin{array}{c}-10.63 \\
(-2.89)\end{array}$ & $\begin{array}{c}\mathbf{0 . 0 0 3}^{\text {**** }} \\
(\mathbf{3 . 8 1})\end{array}$ & $\begin{array}{c}-1.322^{* * *} \\
(-2.80)\end{array}$ \\
\hline SIZE & $\begin{array}{c}\mathbf{0 . 0 0 2}^{* * * *} \\
(16.97)\end{array}$ & $\begin{array}{l}1.95^{* * *} \\
(7.25)\end{array}$ & $\begin{array}{c}1.53^{* * * *} \\
(6.29)\end{array}$ & $\begin{array}{c}-0.0007^{* * *} \\
(-8.16)\end{array}$ & $\begin{array}{l}0.29 * * * * \\
(7.93)\end{array}$ \\
\hline SDUNEMP & $\begin{array}{c}-0.0001^{* * * *} \\
(-3.06)\end{array}$ & $\begin{array}{c}-0.13 \\
(-1.63)\end{array}$ & $\begin{array}{c}-0.09 \\
(-1.34)\end{array}$ & $\begin{array}{c}\mathbf{0 . 0 0 0 0 3}^{*} \\
(1.74)\end{array}$ & $\begin{array}{l}-0.02^{* *} \\
(-2.10)\end{array}$ \\
\hline INCOME & $\begin{array}{c}0.0009^{* * *} \\
(1.97)\end{array}$ & $\begin{array}{l}-5.93^{* * * *} \\
(-7.38)\end{array}$ & $\begin{array}{l}-5.99^{* * * *} \\
(-7.92)\end{array}$ & $\begin{array}{c}0.002 \\
(8.52)\end{array}$ & $\begin{array}{l}-1.15^{* * *} \\
(-10.66)\end{array}$ \\
\hline FOREIGN & $\begin{array}{c}0.00003 \\
(0.01)\end{array}$ & $\begin{array}{l}-13.37^{*} \\
(-1.83)\end{array}$ & $\begin{array}{l}-2.51 \\
(-0.32)\end{array}$ & $\begin{array}{l}0.005^{* * *} \\
(2.46)\end{array}$ & $\begin{array}{c}0.45 \\
(0.57)\end{array}$ \\
\hline LOAN & $\begin{array}{c}-0.0011^{* * * *} \\
(-3.48)\end{array}$ & $\begin{array}{l}-0.273 \\
(-0.32)\end{array}$ & $\begin{array}{c}-0.18 \\
(-0.23)\end{array}$ & $\begin{array}{c}-0.0003 \\
(-1.01)\end{array}$ & $\begin{array}{c}0.19^{*} \\
(1.68)\end{array}$ \\
\hline EQUITY & $\begin{array}{l}\mathbf{0 . 0 6}{ }^{* * * * *} \\
(32.37)\end{array}$ & $\begin{array}{c}24.01^{\text {***** }} \\
(7.92)\end{array}$ & $\begin{array}{c}2.56 \\
(0.93)\end{array}$ & $\begin{array}{c}-0.005^{* * * *} \\
(-5.08)\end{array}$ & $\begin{array}{l}7.81^{* * * *} \\
(19.64)\end{array}$ \\
\hline LIQUID_RISK & $\begin{array}{c}-0.0011^{* * * *} \\
(-2.93)\end{array}$ & $\begin{array}{l}-2.50^{* * * *} \\
(-2.67)\end{array}$ & $\begin{array}{l}-1.44 \\
(-1.64)\end{array}$ & $\begin{array}{c}\mathbf{0 . 0 0 1}{ }^{* * * *} \\
(3.77)\end{array}$ & $\begin{array}{c}-0.59^{* * * *} \\
(-5.01)\end{array}$ \\
\hline SINGLESTATE & $\begin{array}{c}0.00007 \\
(0.70)\end{array}$ & $\begin{array}{c}0.18 \\
(0.75)\end{array}$ & $\begin{array}{c}0.18 \\
(0.75)\end{array}$ & $\begin{array}{c}0.00003 \\
(0.66)\end{array}$ & $\begin{array}{l}0.004 \\
(0.15)\end{array}$ \\
\hline SINGLECOUNTY & $\begin{array}{c}0.0011^{* * * *} \\
(9.83)\end{array}$ & $\begin{array}{l}0.92^{* * * *} \\
(3.70)\end{array}$ & $\begin{array}{l}0.966^{* * * *} \\
(4.07)\end{array}$ & $\begin{array}{c}-0.0001 \\
(-1.45)\end{array}$ & $\begin{array}{c}0.04 \\
(1.52)\end{array}$ \\
\hline Other control & Yes & Yes & Yes & Yes & Yes \\
\hline Year and bank effects & Yes & Yes & Yes & Yes & Yes \\
\hline $\mathrm{N}$ & 50323 & 44021 & 42494 & 44405 & 45242 \\
\hline $\mathrm{n}$ & 6156 & 6019 & 5970 & 5978 & 6001 \\
\hline R2 & 0.146 & 0.0255 & 0.0213 & 0.0376 & 0.0532 \\
\hline K-P statistic & 676.39 & 602.64 & 559.87 & 400.15 & 395.83 \\
\hline J statistic & 1.66 & 1.09 & 1.38 & 3.90 & 5.69 \\
\hline Marginal effect & 0.007 & 5.31 & 7.37 & NS & 0.57 \\
\hline Z statistic & 8.83 & 2.80 & 4.11 & IN. & 2.38 \\
\hline
\end{tabular}


Table A4: Geographic diversification and bank size - Alternative measure of intrastate diversification

This table reports the IV regression results of our baseline model across three sub-samples of bank size (small banks $(\mathrm{TA} \leq \$ 1 \mathrm{~B})$; large banks $(\$ 1 \mathrm{~B}<\mathrm{TA}<\$ 10 \mathrm{~B})$ and very large banks $(\mathrm{TA} \geq \$ 10 \mathrm{~B})$ ) using an alternative measure of intrastate diversification that counts individual MSAs separately but treats non-MSA counties as a single entity from 1994 (Interstate Banking Act) to 2006 (before the global financial crisis of 2007-2008). Explained variables are ROA, RaROA, RaROE, SdROA and logZ. GD: measures of intrastate diversification. Other control: other control variables presented in section 3.4. N: number of observations; n: number of banks. Marginal effect: the marginal effect is calculated as the first derivative of the explained variable with respect to the geographic diversification index computed using the average value of the geographic diversification index. NS: not significant. R2: R squared. K-P statistic: Kleinberger-Paap rk F statistic for weak instrument; J statistics: Hansen-J statistic of overidentifying restrictions. t statistics in parentheses, $* \mathrm{p}<0.1,{ }^{* *} \mathrm{p}<0.05,{ }^{* * *} \mathrm{p}<0.01$. All other variables are defined in Table 1.1.

Small banks $(\mathrm{TA} \leq \$ 1 \mathrm{~B})$

\begin{tabular}{|c|c|c|c|c|c|}
\hline & ROA & RaROA & RaROE & SdROA & $\log Z$ \\
\hline GD & $\begin{array}{c}0.008^{* * *} \\
(5.17)\end{array}$ & $\begin{array}{c}13.97^{* * *} \\
(4.27)\end{array}$ & $\begin{array}{l}9.64^{* * *} \\
(3.19)\end{array}$ & $\begin{array}{c}-0.003^{* * * *} \\
(-3.63)\end{array}$ & $\begin{array}{l}1.20^{* * *} \\
(3.35)\end{array}$ \\
\hline $\mathrm{GD}^{2}$ & $\begin{array}{l}-0.003 \\
(-1.36)\end{array}$ & $\begin{array}{c}-19.90 \\
(-3.65)\end{array}$ & $\begin{array}{l}-10.26 \\
(-2.03)\end{array}$ & $\begin{array}{c}0.005^{* * * *} \\
(3.60)\end{array}$ & $\begin{array}{l}-2.00^{* * * *} \\
(-3.39)\end{array}$ \\
\hline SIZE & $\begin{array}{c}\mathbf{0 . 0 0 3}^{* * * *} \\
(\mathbf{1 5 . 3 5})\end{array}$ & $\begin{array}{c}2.22^{* * * *} \\
(6.66)\end{array}$ & $\begin{array}{l}1.73^{* * * *} \\
(5.61)\end{array}$ & $\begin{array}{c}-0.0008^{* * * *} \\
(-8.07)\end{array}$ & $\begin{array}{c}\mathbf{0 . 3 2} 2^{* * * *} \\
(\mathbf{8 . 2 6})\end{array}$ \\
\hline SDUNEMP & $\begin{array}{c}-0.0001^{* * * *} \\
(-3.76)\end{array}$ & $\begin{array}{l}-0.18^{* *} \\
(-2.06)\end{array}$ & $\begin{array}{l}-0.22^{* * *} \\
(-2.76)\end{array}$ & $\begin{array}{c}0.00003 \\
(1.64)\end{array}$ & $\begin{array}{l}-0.02^{* *} \\
(-2.10)\end{array}$ \\
\hline INCOME & $\begin{array}{c}0.0002 \\
(0.43)\end{array}$ & $\begin{array}{l}-5.12^{* * * * *} \\
(-5.68)\end{array}$ & $\begin{array}{c}-5.42^{* * * *} \\
(-6.33)\end{array}$ & $\begin{array}{c}0.002^{* * * *} \\
(8.65)\end{array}$ & $\begin{array}{l}-1.16^{* * * *} \\
(-10.65)\end{array}$ \\
\hline FOREIGN & $\begin{array}{c}0.02^{*} \\
\text { (1.78) }\end{array}$ & $\begin{array}{l}22.00 \\
(0.84)\end{array}$ & $\begin{array}{l}19.67 \\
(0.79)\end{array}$ & $\begin{array}{c}0.004 \\
(0.47)\end{array}$ & $\begin{array}{c}2.02 \\
(1.20)\end{array}$ \\
\hline LOAN & $\begin{array}{c}-0.001^{* * *} \\
(-2.54)\end{array}$ & $\begin{array}{c}0.18 \\
(0.18)\end{array}$ & $\begin{array}{l}-0.24 \\
(-0.27)\end{array}$ & $\begin{array}{c}-0.0002 \\
(-0.79)\end{array}$ & $\begin{array}{l}0.16 \\
(1.39)\end{array}$ \\
\hline EQUITY & $\begin{array}{l}0.06 \\
(30.19)\end{array}$ & $\begin{array}{c}26.41^{* * *} \\
(7.56)\end{array}$ & $\begin{array}{c}5.14 \\
(1.63)\end{array}$ & $\begin{array}{c}-0.005^{* * *} \\
(-5.28)\end{array}$ & $\begin{array}{l}7.96 \\
(19.61)\end{array}$ \\
\hline LIQUID_RISK & $\begin{array}{c}-0.001^{* *} \\
(-2.34)\end{array}$ & $\begin{array}{l}-2.86^{* * * *} \\
(-2.70)\end{array}$ & $\begin{array}{l}-2.21^{* *} \\
(-2.22)\end{array}$ & $\begin{array}{c}0.001^{* * * *} \\
(3.65)\end{array}$ & $\begin{array}{l}-0.52^{* * *} \\
(-4.28)\end{array}$ \\
\hline SINGLESTATE & $\begin{array}{c}0.00009 \\
(0.80)\end{array}$ & $\begin{array}{c}0.23 \\
(0.82)\end{array}$ & $\begin{array}{c}0.18 \\
(0.66)\end{array}$ & $\begin{array}{c}0.00008 \\
(1.32)\end{array}$ & $\begin{array}{l}-0.013 \\
(-0.41)\end{array}$ \\
\hline SINGLECOUNTY & $\begin{array}{c}0.001^{* * *} \\
(7.59)\end{array}$ & $\begin{array}{l}1.08^{* * * *} \\
(3.74)\end{array}$ & $\begin{array}{l}0.80^{* * * *} \\
(2.90)\end{array}$ & $\begin{array}{r}-0.0001 \\
(-1.88)\end{array}$ & $\begin{array}{l}0.07^{* *} \\
(\mathbf{2 . 1 8})\end{array}$ \\
\hline Other control & Yes & Yes & Yes & Yes & Yes \\
\hline Year and bank effects & Yes & Yes & Yes & Yes & Yes \\
\hline $\mathrm{N}$ & 42601 & 37299 & 35877 & 42652 & 43432 \\
\hline $\mathrm{n}$ & 5701 & 5562 & 5484 & 5720 & 5738 \\
\hline R2 & 0.138 & 0.0249 & 0.0212 & 0.0380 & 0.0541 \\
\hline K-P statistic & 344.79 & 316.31 & 294.27 & 368.36 & 359.48 \\
\hline J statistic & 3.01 & 1.57 & 3.05 & 4.82 & 5.43 \\
\hline $\begin{array}{l}\text { Marginal effect } \\
\text { Z statistic }\end{array}$ & $\begin{array}{c}0.007 \\
6.10\end{array}$ & $\begin{array}{c}11.18 \\
4.31\end{array}$ & $\begin{array}{l}8.21 \\
3.41\end{array}$ & NS & $\begin{array}{l}0.92 \\
3.21\end{array}$ \\
\hline
\end{tabular}

40 
Large banks $(\$ 1 \mathrm{~B}<\mathrm{TA}<\$ 10 \mathrm{~B})$

\begin{tabular}{|c|c|c|c|c|c|}
\hline & ROA & RaROA & RaROE & SdROA & $\log Z$ \\
\hline \multirow[t]{2}{*}{ GD } & 0.0031 & -15.42 & 19.49 & -0.002 & -2.05 \\
\hline & $(0.75)$ & $(-0.87)$ & $(0.99)$ & $(-0.75)$ & $(-1.13)$ \\
\hline \multirow[t]{2}{*}{$\mathrm{GD}^{2}$} & -0.005 & 10.87 & -26.75 & 0.003 & 1.41 \\
\hline & $(-1.23)$ & $(0.66)$ & $(-1.54)$ & (1.14) & $(0.87)$ \\
\hline \multirow[t]{2}{*}{ SIZE } & 0.0002 & 0.74 & 1.64 & 0.00003 & -0.24 \\
\hline & $(0.30)$ & $(0.27)$ & $(0.73)$ & $(0.11)$ & $(-1.10)$ \\
\hline \multirow[t]{2}{*}{ SDUNEMP } & -0.0002 & 0.57 & 0.49 & 0.0001 & -0.01 \\
\hline & $(-1.34)$ & $(0.67)$ & $(0.72)$ & $(1.22)$ & $(-0.25)$ \\
\hline \multirow[t]{2}{*}{ INCOME } & 0.005 & -0.71 & -8.45 & -0.001 & -0.31 \\
\hline & (1.64) & $(-0.10)$ & $(-1.21)$ & $(-0.73)$ & $(-0.42)$ \\
\hline \multirow[t]{2}{*}{ FOREIGN } & -0.0004 & -9.43 & 8.99 & 0.001 & -0.03 \\
\hline & $(-0.16)$ & $(-0.96)$ & $(0.99)$ & $(0.92)$ & $(-0.05)$ \\
\hline \multirow[t]{2}{*}{ LOAN } & -0.003 & 14.02 & 11.98 & -0.003 & 1.32 \\
\hline & $(-0.97)$ & $(1.59)$ & $(1.44)$ & $(-1.50)$ & (1.39) \\
\hline \multirow[t]{2}{*}{ EQUITY } & $0.03^{* * * *}$ & 20.21 & -25.96 & 0.004 & 4.25 \\
\hline & (3.94) & $(0.81)$ & $(-1.21)$ & $(0.95)$ & (1.57) \\
\hline \multirow[t]{2}{*}{ LIQUID_RISK } & $-0.004^{* * *}$ & -7.06 & 6.33 & 0.0005 & $-1.62^{* *}$ \\
\hline & $(-2.21)$ & $(-0.95)$ & $(0.98)$ & $(0.54)$ & $(-2.42)$ \\
\hline \multirow[t]{2}{*}{ SINGLESTATE } & -0.00004 & 0.65 & 0.64 & $-0.0003^{* * *}$ & 0.12 \\
\hline & $(-0.19)$ & $(0.81)$ & $(0.80)$ & $(-2.23)$ & $(1.52)$ \\
\hline \multirow[t]{2}{*}{ SINGLECOUNTY } & -0.0005 & -1.60 & $3.25^{*}$ & 0.0002 & -0.17 \\
\hline & $(-0.99)$ & $(-1.00)$ & (1.68) & $(0.84)$ & $(-0.59)$ \\
\hline Other control & Yes & Yes & Yes & Yes & Yes \\
\hline Year and bank effects & Yes & Yes & Yes & Yes & Yes \\
\hline $\mathrm{N}$ & 1596 & 1291 & 1293 & 1570 & 1620 \\
\hline $\mathrm{n}$ & 312 & 290 & 285 & 312 & 318 \\
\hline $\mathrm{R} 2$ & 0.0806 & 0.0376 & 0.0399 & 0.0437 & 0.0408 \\
\hline K-P statistic & 22.48 & 15.44 & 16.13 & 20.20 & 23.49 \\
\hline J statistic & 0.88 & 4.93 & 2.53 & 2.49 & 0.31 \\
\hline $\begin{array}{l}\text { Marginal effect } \\
Z \text { statistic }\end{array}$ & NS & NS & NS & NS & NS \\
\hline
\end{tabular}


Very large banks ( $\mathrm{TA} \geq \$ 10 \mathrm{~B})$

\begin{tabular}{|c|c|c|c|c|c|}
\hline & ROA & RaROA & RaROE & SdROA & $\log Z$ \\
\hline \multirow[t]{2}{*}{ GD } & 0.0049 & 99.04 & 176.8 & -0.01 & 9.53 \\
\hline & $(0.07)$ & (1.14) & $(1.36)$ & $(-0.74)$ & $(0.79)$ \\
\hline \multirow[t]{2}{*}{$\mathrm{GD}^{2}$} & 0.014 & -75.21 & -132.5 & 0.02 & -9.97 \\
\hline & $(0.27)$ & $(-1.11)$ & $(-1.32)$ & $(1.44)$ & $(-1.08)$ \\
\hline \multirow[t]{2}{*}{ SIZE } & 0.002 & $13.97^{* * * *}$ & $14.59^{* * * *}$ & $-0.001^{*}$ & $1.11^{* *}$ \\
\hline & $(1.19)$ & $(2.90)$ & (3.17) & $(-1.86)$ & $(2.44)$ \\
\hline \multirow[t]{2}{*}{ SDUNEMP } & 0.0003 & 0.96 & $3.006 *$ & -0.00005 & 0.09 \\
\hline & $(0.92)$ & $(0.97)$ & $(2.03)$ & $(-0.36)$ & $(1.06)$ \\
\hline \multirow[t]{2}{*}{ INCOME } & 0.02 & 25.30 & 92.18 & -0.01 & 8.02 \\
\hline & $(1.24)$ & $(0.40)$ & $(1.35)$ & $(-1.16)$ & $(1.56)$ \\
\hline \multirow[t]{2}{*}{ FOREIGN } & 0.02 & -43.10 & -32.18 & $0.02^{* * * *}$ & $-8.35^{* *}$ \\
\hline & $(1.56)$ & $(-1.18)$ & $(-0.78)$ & (3.79) & $(-2.19)$ \\
\hline \multirow[t]{2}{*}{ LOAN } & -0.003 & $58.42^{* * *}$ & $\mathbf{7 0 . 5 0}$ *** & $-0.009^{*}$ & 6.56 ** \\
\hline & $(-0.35)$ & (2.28) & $(2.16)$ & $(-1.73)$ & (2.17) \\
\hline \multirow[t]{2}{*}{ EQUITY } & 0.01 & -26.52 & $-198.7^{* *}$ & 0.005 & -3.03 \\
\hline & $(0.38)$ & $(-0.40)$ & $(-1.97)$ & $(0.37)$ & $(-0.36)$ \\
\hline \multirow[t]{2}{*}{ LIQUID_RISK } & -0.0005 & 33.36 & 33.87 & $-0.009^{* *}$ & 3.6 \\
\hline & $(-0.07)$ & $(1.15)$ & (1.18) & $(-2.30)$ & $(1.52)$ \\
\hline \multirow[t]{2}{*}{ SINGLESTATE } & 0.002 & $11.39^{* * * *}$ & $7.54^{*}$ & $-0.002^{* * * *}$ & $1.07^{* * *}$ \\
\hline & $(0.85)$ & $(2.95)$ & (1.87) & $(-2.97)$ & (3.01) \\
\hline \multicolumn{6}{|l|}{ SINGLECOUNTY } \\
\hline Other control & Yes & Yes & Yes & Yes & Yes \\
\hline Year and bank effects & Yes & Yes & Yes & Yes & Yes \\
\hline $\mathrm{N}$ & 118 & 106 & 100 & 116 & 118 \\
\hline $\mathrm{n}$ & 23 & 22 & 22 & 23 & 23 \\
\hline $\mathrm{R} 2$ & 0.323 & 0.382 & 0.364 & 0.426 & 0.398 \\
\hline K-P statistic & 7.21 & 7.49 & 5.32 & 6.18 & 6.51 \\
\hline $\mathrm{J}$ statistic & 5.13 & $8.19 *$ & 6.44 & 5.04 & $7.93 *$ \\
\hline $\begin{array}{l}\text { Marginal effect } \\
\text { Z statistic }\end{array}$ & NS & NS & NS & NS & NS \\
\hline
\end{tabular}


Table A5: Effect of Geographic Diversification on Bank Risk and Performance - only BHC

This table reports the IV regression results of our baseline model using GD1 and GD2 respectively as measure of geographic diversification (GD) from 1994 (Interstate Banking Act) to 2006 (before the global financial crisis of 2007-2008). Explained variables are ROA, RaROA, RaROE, SdROA and logZ. GD: measures of intrastate diversification or interstate diversification. Other control: other control variables presented in section 3.4. N: number of observations; n: number of banks. The marginal effect is calculated as the first derivative of the explained variable with respect to the geographic diversification index computed using the average value of the geographic diversification index. NS: not significant. K-P statistic: Kleinberger-Paap rk F statistic for weak instrument; J statistics: Hansen-J statistic of overidentifying restrictions. $t$ statistics in parentheses, * $p<0.1$, ** $p$ $<0.05,{ }^{* * *} \mathrm{p}<0.01$. All other variables are defined in Table 1.1. All models include bank and year effects.

\begin{tabular}{|c|c|c|c|c|c|c|c|c|c|c|}
\hline & \multicolumn{5}{|c|}{ Intrastate diversification } & \multicolumn{5}{|c|}{ Interstate diversification } \\
\hline & ROA & RaROA & RaROE & SdROA & $\log Z$ & ROA & RaROA & RaROE & SdROA & $\log Z$ \\
\hline \multirow[t]{2}{*}{ GD } & $0.011^{* * * *}$ & $10.07^{* * * * *}$ & $9.14^{* * * *}$ & $-0.001 *$ & $0.83^{* * *}$ & $0.0066^{* * * *}$ & 4.89 & $12.54^{* * * *}$ & $-0.001^{*}$ & $0.89^{*}$ \\
\hline & (7.37) & (3.48) & (3.33) & $(-1.83)$ & $(2.20)$ & $(4.05)$ & $(1.12)$ & (2.76) & $(-1.90)$ & (1.87) \\
\hline \multirow[t]{2}{*}{$\mathrm{GD}^{2}$} & $-0.008^{* * * *}$ & $-9.46^{* * * *}$ & $-7.77^{* *}$ & $0.001^{*}$ & $-0.78^{*}$ & $-0.004^{*}$ & -5.65 & $-19.19^{* *}$ & $0.003^{* * *}$ & -1.08 \\
\hline & $(-5.12)$ & $(-2.69)$ & $(-2.34)$ & (1.72) & $(-1.72)$ & $(-1.78)$ & $(-0.75)$ & $(-2.38)$ & $(2.13)$ & $(-1.30)$ \\
\hline \multirow[t]{2}{*}{ SIZE } & $0.002^{* * * * *}$ & $1.68^{* * * *}$ & $1.13^{\text {**** }}$ & $-0.0006^{* * * *}$ & $0.25^{* * *}$ & $0.002^{* * * *}$ & $1.06^{* * *}$ & $0.99^{* * * *}$ & $-0.0005^{* * * *}$ & $0.22^{* * * *}$ \\
\hline & (12.83) & $(5.49)$ & $(4.07)$ & $(-5.95)$ & $(5.94)$ & (12.07) & (3.91) & $(4.01)$ & $(-7.55)$ & (6.78) \\
\hline \multirow[t]{2}{*}{ SDUNEMP } & $-0.00008^{* * *}$ & -0.11 & -0.12 & 0.00001 & -0.0148 & $-0.00008^{* *}$ & -0.12 & -0.12 & 0.00001 & -0.01 \\
\hline & $(-2.11)$ & $(-1.30)$ & $(-1.50)$ & (0.69) & $(-1.45)$ & $(-2.25)$ & $(-1.41)$ & $(-1.49)$ & $(0.64)$ & $(-1.31)$ \\
\hline \multirow[t]{2}{*}{ INCOME } & $0.0009^{*}$ & $-5.99^{* * *}$ & $-5.87^{* * *}$ & $0.002^{* * * *}$ & $-1.21^{* * *}$ & 0.0008 & $-6.12^{* * *}$ & $-5.81^{* * *}$ & $0.002^{* * *}$ & $-1.29^{* * * *}$ \\
\hline & (1.77) & $(-6.52)$ & $(-6.77)$ & (6.93) & $(-9.94)$ & $(1.57)$ & $(-6.68)$ & $(-6.72)$ & (8.67) & $(-11.70)$ \\
\hline \multirow[t]{2}{*}{ FOREIGN } & -0.003 & $-15.43^{*}$ & -3.42 & $0.004^{* * *}$ & 0.44 & -0.002 & $-14.59^{*}$ & -4.53 & $0.005^{* * *}$ & 0.27 \\
\hline & $(-1.35)$ & $(-1.87)$ & $(-0.41)$ & (2.36) & $(0.46)$ & $(-1.02)$ & $(-1.77)$ & $(-0.54)$ & (2.78) & $(0.22)$ \\
\hline \multirow[t]{2}{*}{ LOAN } & $-0.001^{* *}$ & -0.24 & 0.04 & $-0.0006^{*}$ & $0.23^{*}$ & $-0.001^{* *}$ & -0.26 & -0.035 & -0.0001 & 0.087 \\
\hline & $(-2.50)$ & $(-0.24)$ & $(0.05)$ & $(-1.87)$ & $(1.72)$ & $(-2.44)$ & $(-0.25)$ & $(-0.04)$ & $(-0.34)$ & $(0.73)$ \\
\hline \multirow[t]{2}{*}{ EQUITY } & $0.06^{* * *}$ & $24.47^{* * * *}$ & -0.05 & $-0.003^{* * * *}$ & $7.47^{* * *}$ & $0.055^{* * * *}$ & $22.066^{* * * *}$ & -1.09 & $-0.003^{* * * *}$ & $7.47^{* * * *}$ \\
\hline & $(28.07)$ & $(6.80)$ & $(-0.02)$ & $(-3.50)$ & $(16.00)$ & $(27.61)$ & (6.22) & $(-0.34)$ & $(-3.76)$ & (18.00) \\
\hline \multirow[t]{2}{*}{ LIQUID_RISK } & $-0.001^{* * * *}$ & $-3.11^{* * * *}$ & $-1.91^{*}$ & $0.001^{* * *}$ & $-0.66^{* * * *}$ & $-0.001^{* * *}$ & $-3.79^{* * *}$ & $-2.05^{* *}$ & $0.001^{* * * *}$ & $-0.63^{* * * *}$ \\
\hline & $(-2.62)$ & $(-2.95)$ & $(-1.91)$ & $(4.54)$ & $(-4.97)$ & $(-3.66)$ & $(-3.62)$ & $(-2.06)$ & $(4.46)$ & $(-5.28)$ \\
\hline \multirow[t]{2}{*}{ SINGLESTATE } & -0.00004 & 0.18 & 0.06 & 0.00001 & 0.02 & 0.00004 & 0.27 & 0.39 & 0.00001 & 0.02 \\
\hline & $(-0.42)$ & $(0.71)$ & $(0.26)$ & $(0.18)$ & $(0.69)$ & $(0.35)$ & $(0.91)$ & $(1.34)$ & $(0.23)$ & $(0.66)$ \\
\hline \multirow[t]{2}{*}{ SINGLECOUNTY } & $0.001^{* * * *}$ & $1.79^{* * * *}$ & $1.79^{* * *}$ & -0.00007 & $0.09^{*}$ & $0.001^{* * * *}$ & $0.93^{* * *}$ & $0.86^{* * *}$ & $-0.0001^{* * *}$ & $0.09^{* * * *}$ \\
\hline & (8.41) & (4.13) & $(4.34)$ & $(-0.56)$ & (1.65) & $(10.76)$ & $(4.24)$ & $(4.14)$ & $(-2.37)$ & (3.71) \\
\hline Other control & Yes & Yes & Yes & Yes & Yes & Yes & Yes & Yes & Yes & Yes \\
\hline Year and Bank Effects & Yes & Yes & Yes & Yes & Yes & Yes & Yes & Yes & Yes & Yes \\
\hline $\mathrm{N}$ & 39450 & 34727 & 33458 & 34807 & 35413 & 39450 & 34727 & 33458 & 34807 & 35413 \\
\hline $\mathrm{n}$ & 4824 & 4731 & 4688 & 4671 & 4683 & 4824 & 4731 & 4688 & 4671 & 4683 \\
\hline $\mathrm{R} 2$ & 0.146 & 0.0260 & 0.0215 & 0.0397 & 0.0536 & 0.146 & 0.0260 & 0.0215 & 0.0397 & 0.0536 \\
\hline K-P statistic & 479.25 & 443.68 & 393.43 & 307.41 & 291.99 & 289.40 & 243.20 & 225.93 & 270.16 & 283.98 \\
\hline J statistic & 0.29 & 0.89 & 1.52 & 5.18 & 6.86 & 2.46 & 1.37 & 3.02 & 5.19 & 1.78 \\
\hline Marginal effect & 0.0077 & 7.45 & 6.99 & NS & 0.61 & 0.006 & NS & 12.01 & NS & NS \\
\hline z statistic & 8.04 & 3.68 & 3.65 & NS & 2.14 & 4.13 & INS & 2.76 & INS & NS \\
\hline
\end{tabular}


Table A6: Geographic diversification and bank size - only BHC

This table reports the IV regression results of our baseline model across three sub-samples of bank size (small banks $(\mathrm{TA} \leq \$ 1 \mathrm{~B})$; large banks $(\$ 1 \mathrm{~B}<\mathrm{TA}<\$ 10 \mathrm{~B})$ and very large banks (TA $\geq \$ 10 B$ )) using GD1 and GD2 respectively as measure of geographic diversification (GD) from 1994 (Interstate Banking Act) to 2006 (before the global financial crisis of 2007-2008). Explained variables are ROA, RaROA, RaROE, SdROA and logZ. GD: measures of intrastate diversification or interstate diversification. Other control: other control variables presented in section 3.4. N: number of observations; $n$ : number of banks. Marginal effect: the marginal effect is calculated as the first derivative of the explained variable with respect to the geographic diversification index computed using the average value of the geographic diversification index. NS: not significant. R2: R squared. K-P statistic: Kleinberger-Paap rk F statistic for weak instrument; J statistics: Hansen-J statistic of overidentifying restrictions. $t$ statistics in parentheses, ${ }^{*} \mathrm{p}<0.1, * * \mathrm{p}<0.05, * * * \mathrm{p}<$ 0.01. All other variables are defined in Table 1.1.

Small banks $(\mathrm{TA} \leq \$ 1 \mathrm{~B})$

\begin{tabular}{|c|c|c|c|c|c|c|c|c|c|c|}
\hline & \multicolumn{5}{|c|}{ Intrastate diversification } & \multicolumn{5}{|c|}{ Interstate diversification } \\
\hline & ROA & RaROA & RaROE & SdROA & $\log Z$ & ROA & RaROA & RaROE & SdROA & $\log Z$ \\
\hline \multirow[t]{2}{*}{ GD } & $0.01^{* * * *}$ & $13.44^{* * *}$ & $9.62^{* * * *}$ & $-0.002^{* * *}$ & $1.14^{* * * *}$ & $0.006 *$ & 7.03 & 5.84 & -0.0005 & 0.12 \\
\hline & (6.09) & (3.65) & $(2.74)$ & $(-1.98)$ & $(2.76)$ & (1.84) & $(0.90)$ & $(0.72)$ & $(-0.27)$ & $(0.15)$ \\
\hline \multirow[t]{2}{*}{$\mathrm{GD}^{2}$} & $-0.007^{* * *}$ & $-12.27^{* * *}$ & -6.99 & $0.002^{*}$ & $-1.09^{* *}$ & -0.001 & -5.40 & 1.53 & -0.001 & 1.17 \\
\hline & $(-3.62)$ & $(-2.64)$ & $(-1.58)$ & (1.71) & $(-2.13)$ & $(-0.12)$ & $(-0.32)$ & $(0.08)$ & $(-0.27)$ & $(0.63)$ \\
\hline \multirow[t]{2}{*}{ SIZE } & $0.00 \%$ "**** & $2.00^{* * * *}$ & $1.44^{* * * *}$ & $-0.0006^{* * * *}$ & $0.28^{* * * *}$ & $0.002^{* * * *}$ & $1.29^{* * * *}$ & $1.19^{* * * *}$ & $-0.0006^{* * * *}$ & $0.24^{* * * *}$ \\
\hline & $(\mathbf{1 1 . 5 3 )}$ & $(5.12)$ & $(4.01)$ & $(-5.89)$ & $(6.29)$ & (11.94) & $(4.57)$ & $(4.50)$ & $(-7.55)$ & (7.18) \\
\hline \multirow[t]{2}{*}{ SDUNEMP } & $-0.0001^{* * * *}$ & -0.15 & $-0.28^{* * *}$ & 0.00001 & -0.01 & $-0.00008^{* * *}$ & -0.12 & $-0.15^{*}$ & 0.00001 & -0.01 \\
\hline & $(-2.66)$ & $(-1.54)$ & $(-3.05)$ & $(0.62)$ & $(-1.38)$ & $(-2.26)$ & $(-1.40)$ & $(-1.88)$ & $(0.52)$ & $(-1.27)$ \\
\hline \multirow[t]{2}{*}{ INCOME } & 0.0002 & $-5.52^{* * *}$ & $-5.33^{* * *}$ & $0.002^{* * *}$ & $-1.21^{* * * *}$ & 0.0007 & $-6.08^{* * * *}$ & $-5.66^{* * * *}$ & $0.002^{* * *}$ & $-1.28^{* * *}$ \\
\hline & $(0.37)$ & $(-5.34)$ & $(-5.40)$ & (7.10) & $(-9.78)$ & (1.39) & $(-6.54)$ & $(-6.45)$ & (8.81) & $(-11.44)$ \\
\hline \multirow[t]{2}{*}{ FOREIGN } & $-0.04^{* * * *}$ & $-94.16^{* * * *}$ & $-70.85^{* * *}$ & 0.006 & $-8.16^{* * *}$ & $-0.06^{* * * *}$ & $-115.90^{* * * *}$ & $-89.43^{* * *}$ & $0.012^{* * *}$ & $-11.50^{* * *}$ \\
\hline & $(-4.29)$ & $(-3.49)$ & $(-3.12)$ & $(1.54)$ & $(-2.15)$ & $(-2.90)$ & $(-3.41)$ & $(-3.01)$ & $(2.65)$ & $(-2.88)$ \\
\hline \multirow[t]{2}{*}{ LOAN } & $-0.001^{* * *}$ & 0.50 & 0.11 & -0.0005 & 0.20 & $-0.001^{* *}$ & -0.10 & -0.12 & -0.00005 & 0.067 \\
\hline & $(-2.16)$ & $(0.42)$ & $(0.10)$ & $(-1.61)$ & $(1.51)$ & $(-2.35)$ & $(-0.10)$ & $(-0.13)$ & $(-0.17)$ & $(0.56)$ \\
\hline \multirow[t]{2}{*}{ EQUITY } & $0.066^{* * *}$ & $29.88^{* * *}$ & 4.82 & $-0.004^{* * *}$ & $7.78^{* * *}$ & $0.05^{* * *}$ & $23.01^{* * * *}$ & 0.77 & $-0.004^{* * *}$ & $7.75^{* * *}$ \\
\hline & (26.33) & (7.12) & $(1.28)$ & $(-3.86)$ & (16.21) & $(27.20)$ & (6.37) & $(0.24)$ & $(-4.19)$ & (18.27) \\
\hline \multirow[t]{2}{*}{ LIQUID_RISK } & -0.0009 & $-3.19^{* * * *}$ & $-2.46^{* * *}$ & $0.001^{* * *}$ & $-0.58^{* * * *}$ & $-0.001^{* * *}$ & $-3.55^{* * *}$ & $-2.29^{* *}$ & $0.0012^{* * *}$ & $-0.60^{* * *}$ \\
\hline & $(-1.57)$ & $(-2.64)$ & $(-2.16)$ & $(4.42)$ & $(-4.18)$ & $(-3.00)$ & $(-3.32)$ & $(-2.26)$ & $(4.52)$ & $(-4.86)$ \\
\hline \multirow[t]{2}{*}{ SINGLESTATE } & -0.00002 & 0.20 & 0.09 & 0.00006 & 0.0001 & 0.0001 & 0.47 & 0.33 & 0.00006 & -0.004 \\
\hline & $(-0.21)$ & $(0.68)$ & $(0.32)$ & $(0.94)$ & $(0.00)$ & $(0.85)$ & $(1.36)$ & $(0.99)$ & $(0.87)$ & $(-0.11)$ \\
\hline \multirow[t]{2}{*}{ SINGLECOUNTY } & $0.002^{* * *}$ & $2.04^{* * * *}$ & $1.72^{* * * *}$ & -0.0001 & $0.13^{* * *}$ & $0.001^{* * *}$ & $1.00^{* * * *}$ & $0.93^{* * * *}$ & $-0.0001^{* * * *}$ & $0.10 * * *$ \\
\hline & (6.99) & (3.92) & $(3.44)$ & $(-0.89)$ & (2.33) & (11.06) & $(4.48)$ & $(4.43)$ & $(-2.88)$ & $(4.33)$ \\
\hline Other control & Yes & Yes & Yes & Yes & Yes & Yes & Yes & Yes & Yes & Yes \\
\hline Year and Bank Effects & Yes & Yes & Yes & Yes & Yes & Yes & Yes & Yes & Yes & Yes \\
\hline $\mathrm{N}$ & 33098 & 29186 & 28003 & 33121 & 33676 & 37552 & 33171 & 31910 & 37543 & 38162 \\
\hline $\mathrm{n}$ & 4413 & 4322 & 4254 & 4423 & 4430 & 4585 & 4491 & 4451 & 4590 & 4597 \\
\hline $\mathrm{R} 2$ & 0.138 & 0.0252 & 0.0206 & 0.0403 & 0.0547 & 0.149 & 0.0267 & 0.0222 & 0.0447 & 0.0590 \\
\hline K-P statistic & 294.09 & 239.26 & 220.71 & 269.61 & 261.64 & 124.78 & 105.53 & 103.52 & 127.75 & 128.42 \\
\hline $\mathrm{J}$ statistic & 7.43 & 0.51 & 1.97 & 6.24 & $8.10^{*}$ & 0.55 & 1.89 & 0.48 & $5.06 *$ & 0.62 \\
\hline Marginal effect & 0.009 & 10.39 & 7.88 & NS & 0.87 & NS & $\mathrm{NS}$ & $\mathrm{NS}$ & NS & NS \\
\hline z statistic & 6.84 & 3.94 & 3.15 & IVS & 2.91 & IVS & ND & NS & NS & NS \\
\hline
\end{tabular}


Large banks $(\$ 1 \mathrm{~B}<\mathrm{TA}<\$ 10 \mathrm{~B})$

\begin{tabular}{|c|c|c|c|c|c|c|c|c|c|c|}
\hline & \multicolumn{5}{|c|}{ Intrastate diversification } & \multicolumn{5}{|c|}{ Interstate diversification } \\
\hline & ROA & RaROA & RaROE & SdROA & $\log Z$ & ROA & RaROA & RaROE & SdROA & $\log Z$ \\
\hline \multirow[t]{2}{*}{ GD } & 0.005 & -14.12 & 14.00 & -0.002 & -1.15 & -0.0002 & -12.64 & 1.98 & -0.003 & 0.60 \\
\hline & $(1.12)$ & $(-0.87)$ & $(0.75)$ & $(-0.83)$ & $(-0.67)$ & $(-0.06)$ & $(-0.93)$ & $(0.16)$ & $(-1.35)$ & $(0.43)$ \\
\hline \multirow[t]{2}{*}{$\mathrm{GD}^{2}$} & -0.006 & 8.29 & -21.32 & 0.003 & 0.26 & -0.006 & 6.679 & -13.72 & $0.0049^{* * *}$ & -1.00 \\
\hline & $(-1.49)$ & $(0.56)$ & $(-1.30)$ & $(1.14)$ & $(0.17)$ & $(-1.59)$ & $(0.43)$ & $(-0.88)$ & $(2.01)$ & $(-0.57)$ \\
\hline \multirow[t]{2}{*}{ SIZE } & 0.0002 & -0.98 & -0.29 & -0.00002 & -0.24 & -0.0002 & -0.866 & -1.11 & -0.00002 & -0.11 \\
\hline & $(0.30)$ & $(-0.40)$ & $(-0.14)$ & $(-0.08)$ & $(-1.17)$ & $(-0.26)$ & $(-0.38)$ & $(-0.63)$ & $(-0.09)$ & $(-0.60)$ \\
\hline \multirow[t]{2}{*}{ SDUNEMP } & -0.0002 & 1.01 & 0.83 & 0.00006 & -0.04 & -0.0002 & 0.759 & 0.93 & 0.00003 & -0.01 \\
\hline & $(-1.20)$ & (1.14) & (1.14) & $(0.53)$ & $(-0.64)$ & $(-1.13)$ & $(0.97)$ & (1.39) & $(0.32)$ & $(-0.19)$ \\
\hline \multirow[t]{2}{*}{ INCOME } & 0.0052 & -1.14 & -8.52 & -0.001 & -0.39 & 0.003 & -0.938 & $-11.80^{*}$ & -0.001 & -0.51 \\
\hline & (1.63) & $(-0.15)$ & $(-1.21)$ & $(-1.05)$ & $(-0.53)$ & $(1.30)$ & $(-0.14)$ & $(-1.81)$ & $(-0.85)$ & $(-0.76)$ \\
\hline \multirow[t]{2}{*}{ FOREIGN } & -0.00001 & -6.54 & 12.62 & 0.001 & -0.03 & -0.0005 & -7.354 & 14.47 & 0.002 & -0.33 \\
\hline & $(-0.01)$ & $(-0.65)$ & (1.32) & $(1.11)$ & $(-0.05)$ & $(-0.23)$ & $(-0.75)$ & $(1.46)$ & $(1.50)$ & $(-0.39)$ \\
\hline \multirow[t]{2}{*}{ LOAN } & $-0.00 "$ & 13.81 & 12.17 & -0.003 & 0.68 & -0.001 & 12.55 & 12.99 & $-0.002^{*}$ & 0.68 \\
\hline & $(-0.79)$ & $(1.53)$ & $(1.43)$ & $(-1.52)$ & $(0.71)$ & $(-0.45)$ & $(1.49)$ & $(1.62)$ & $(-1.68)$ & $(0.78)$ \\
\hline \multirow[t]{2}{*}{ EQUITY } & $0.03^{* * *}$ & 8.03 & $-42.47^{*}$ & 0.007 & 2.18 & $0.04^{* * * *}$ & 9.290 & -29.48 & 0.006 & 3.00 \\
\hline & (3.38) & $(0.30)$ & $(-1.85)$ & $(1.32)$ & $(0.74)$ & $(4.53)$ & $(0.39)$ & $(-1.35)$ & $(1.22)$ & $(1.10)$ \\
\hline \multirow[t]{2}{*}{ LIQUID_RISK } & $-0.004^{* *}$ & -9.77 & 5.23 & 0.0003 & $-1.59^{* *}$ & $-0.004^{* *}$ & -7.294 & 8.88 & -0.0001 & -0.79 \\
\hline & $(-2.27)$ & $(-1.30)$ & $(0.79)$ & $(0.32)$ & $(-2.30)$ & $(-2.49)$ & $(-1.07)$ & $(1.41)$ & $(-0.14)$ & $(-1.22)$ \\
\hline \multirow[t]{2}{*}{ SINGLESTATE } & -0.00004 & 0.74 & 0.66 & $-0.0003^{* *}$ & $0.15^{*}$ & -0.0001 & -0.0994 & 0.68 & $-0.0003^{* *}$ & $0.17^{*}$ \\
\hline & $(-0.17)$ & $(0.88)$ & $(0.80)$ & $(-2.34)$ & (1.85) & $(-0.59)$ & $(-0.12)$ & $(0.82)$ & $(-2.57)$ & (1.96) \\
\hline \multirow[t]{2}{*}{ SINGLECOUNTY } & -0.0004 & -1.94 & 2.54 & 0.0003 & -0.17 & -0.0005 & -1.509 & 0.37 & $0.0005^{* *}$ & -0.21 \\
\hline & $(-0.78)$ & $(-1.14)$ & $(1.24)$ & $(0.99)$ & $(-0.89)$ & $(-1.13)$ & $(-0.97)$ & $(0.20)$ & $(2.09)$ & $(-1.30)$ \\
\hline Other control & Yes & Yes & Yes & Yes & Yes & Yes & Yes & Yes & Yes & Yes \\
\hline Year and Bank Effects & Yes & Yes & Yes & Yes & Yes & Yes & Yes & Yes & Yes & Yes \\
\hline $\mathrm{N}$ & 1527 & 1233 & 1235 & 1506 & 1551 & 1695 & 1361 & 1360 & 1669 & 1719 \\
\hline $\mathrm{n}$ & 301 & 279 & 274 & 301 & 307 & 315 & 290 & 284 & 313 & 320 \\
\hline $\mathrm{R} 2$ & 0.0793 & 0.0435 & 0.0399 & 0.0485 & 0.0409 & 0.0826 & 0.0312 & 0.0351 & 0.0502 & 0.0376 \\
\hline K-P statistic & 22.33 & 14.53 & 16.21 & 18.33 & 23.06 & 25.05 & 23.54 & 28.13 & 26.51 & 28.10 \\
\hline J statistic & 1.83 & 2.64 & 1.62 & 3.87 & 1.60 & 2.16 & 4.38 & 2.50 & 0.99 & 2.09 \\
\hline $\begin{array}{l}\text { Marginal effect } \\
\text { z statistic }\end{array}$ & NS & NS & NS & NS & NS & NS & NS & NS & NS & $\mathrm{NS}$ \\
\hline
\end{tabular}


Very large banks (TA $\geq \$ 10 \mathrm{~B})$

\begin{tabular}{|c|c|c|c|c|c|c|c|c|c|c|}
\hline & \multicolumn{5}{|c|}{ Intrastate diversification } & \multicolumn{5}{|c|}{ Interstate diversification } \\
\hline & ROA & RaROA & RaROE & SdROA & $\log Z$ & ROA & RaROA & RaROE & SdROA & $\log Z$ \\
\hline \multirow[t]{2}{*}{ GD } & 0.018 & 101.3 & 172.4 & -0.015 & 9.98 & -0.0006 & 78.47 & 22.88 & -0.0107 & $9.252^{* * *}$ \\
\hline & $(0.25)$ & $(1.17)$ & $(1.33)$ & $(-0.79)$ & $(0.88)$ & $(-0.04)$ & $(1.36)$ & $(0.40)$ & $(-1.33)$ & (1.99) \\
\hline $\mathrm{GD}^{2}$ & $(0.07)$ & $(-1.17)$ & $(-1.32)$ & $(1.52)$ & $(-1.22)$ & $(0.42)$ & $(-1.11)$ & $(-0.40)$ & (1.53) & $(-2.03)$ \\
\hline \multirow[t]{2}{*}{ SIZE } & 0.0018 & $13.75^{* * * *}$ & $14.40^{* * * *}$ & $-0.001 *$ & $1.06^{* *}$ & 0.001 & $7.98^{* *}$ & $7.49^{*}$ & -0.000919 & $0.889^{* * *}$ \\
\hline & $(1.24)$ & $(2.93)$ & (3.19) & $(-1.80)$ & (2.38) & $(0.92)$ & (2.16) & (1.81) & $(-1.34)$ & (1.98) \\
\hline SDUNEMP & $(0.66)$ & $(1.22)$ & $(2.02)$ & $(-0.94)$ & $(1.46)$ & $(0.63)$ & $(1.21)$ & $(1.61)$ & $(0.12)$ & $(-0.23)$ \\
\hline \multirow[t]{2}{*}{ INCOME } & 0.02 & 24.10 & 90.23 & -0.009 & 7.49 & 0.01 & 62.42 & 66.19 & -0.0108 & $9.629^{* * *}$ \\
\hline & $(1.36)$ & $(0.39)$ & $(1.34)$ & $(-1.07)$ & $(1.52)$ & $(1.33)$ & $(1.20)$ & $(1.21)$ & $(-1.33)$ & $(2.13)$ \\
\hline \multirow[t]{2}{*}{ FOREIGN } & 0.01 & -42.72 & -30.50 & $0.02^{* * * *}$ & $-8.25^{* *}$ & 0.004 & -27.15 & -13.08 & $0.00752^{*}$ & -2.076 \\
\hline & $(1.54)$ & $(-1.17)$ & $(-0.74)$ & (3.82) & $(-2.23)$ & $(0.54)$ & $(-1.07)$ & $(-0.51)$ & (1.69) & $(-0.77)$ \\
\hline LOAN & -0.002 & $58.65^{* *}$ & $70.51^{* *}$ & $-0.009^{*}$ & $6.65^{* *}$ & -0.006 & $60.79^{* *}$ & 31.78 & $-0.00962^{* *}$ & $7.782^{* * * *}$ \\
\hline LIQUID_RISK & $(-0.08)$ & $(1.13)$ & (1.13) & $(-2.25)$ & $(1.51)$ & $(0.71)$ & $(-0.23)$ & $(0.68)$ & $(-1.04)$ & (1.67) \\
\hline \multirow[t]{2}{*}{ SINGLESTATE } & 0.002 & $11.24^{* * *}$ & $7.45^{*}$ & $-0.001^{* * * *}$ & $1.02^{* * * *}$ & $0.002^{*}$ & $13.71^{* *}$ & 7.60 & $-0.00199^{* *}$ & $1.398^{* * * *}$ \\
\hline & $(0.80)$ & (2.96) & (1.83) & $(-2.90)$ & (3.05) & $(1.82)$ & $(2.40)$ & $(1.63)$ & $(-2.53)$ & $(2.94)$ \\
\hline \multicolumn{11}{|l|}{ SINGLECOUNTY } \\
\hline Other control & Yes & Yes & Yes & Yes & Yes & Yes & Yes & Yes & Yes & Yes \\
\hline Year and Bank Effects & Yes & Yes & Yes & Yes & Yes & Yes & Yes & Yes & Yes & Yes \\
\hline $\mathrm{N}$ & 118 & 106 & 100 & 116 & 118 & 130 & 115 & 111 & 128 & 130 \\
\hline $\mathrm{n}$ & 23 & 22 & 22 & 23 & 23 & 23 & 22 & 22 & 23 & 23 \\
\hline $\mathrm{R} 2$ & 0.324 & 0.383 & 0.363 & 0.425 & 0.398 & 0.354 & 0.334 & 0.344 & 0.407 & 0.395 \\
\hline K-P statistic & 6.54 & 6.20 & 5.22 & 6.13 & 6.36 & 22.35 & 14.02 & 18.03 & 21.22 & 22.34 \\
\hline
\end{tabular}


Table A7: Geographic diversification and bank risk (CRED_RISK)

This table reports the IV regression results of our baseline model for the whole sample and across three sub-samples of bank size (small banks (TA $\leq \$ 1 \mathrm{~B})$; large banks $(\$ 1 \mathrm{~B}<\mathrm{TA}$ $<\$ 10 \mathrm{~B}$ ) and very large banks (TA $\geq \$ 10 \mathrm{~B})$ ) using GD1 and GD2 respectively as measure of geographic diversification (GD) from 1994 (Interstate Banking Act) to 2006 (before the global financial crisis of 2007-2008). GD: measures of intrastate diversification or interstate diversification. Other control: other control variables presented in section 3.4. N: number of observations; n: number of banks. Marginal effect: the marginal effect is calculated as the first derivative of the explained variable with respect to the geographic diversification index computed using the average value of the geographic diversification index. NS: not significant. R2: R squared. K-P statistic: Kleinberger-Paap rk F statistic for weak instrument; J statistics: Hansen-J statistic of overidentifying restrictions. $t$ statistics in parentheses, $* \mathrm{p}<0.1, * * \mathrm{p}<0.05$, ${ }^{* * *} \mathrm{p}<0.01$. All other variables are defined in Table 1.1.

\begin{tabular}{|c|c|c|c|c|c|c|c|c|}
\hline & \multicolumn{4}{|c|}{ Intrastate diversification } & \multicolumn{4}{|c|}{ Interstate diversification } \\
\hline & Whole sample & Small banks & Large Banks & Very Large banks & Whole sample & Small banks & Large Banks & Very Large banks \\
\hline \multirow[t]{2}{*}{ GD } & $0.004^{* * * *}$ & $0.005^{* * *}$ & -0.00009 & -0.01 & 0.001 & -0.0004 & 0.005 & 0.03 \\
\hline & (3.27) & $(3.47)$ & $(-0.03)$ & $(-0.30)$ & $(0.67)$ & $(-0.12)$ & $(1.49)$ & $(1.58)$ \\
\hline \multirow[t]{2}{*}{$\mathrm{GD}^{2}$} & $-0.003^{*}$ & $-0.004^{* *}$ & 0.004 & 0.006 & -0.001 & 0.001 & -0.002 & $-0.03^{*}$ \\
\hline & $(-1.94)$ & $(-2.22)$ & $(1.25)$ & $(0.17)$ & $(-0.46)$ & $(0.20)$ & $(-0.65)$ & $(-1.91)$ \\
\hline \multirow[t]{2}{*}{ SIZE } & 0.0001 & 0.0002 & 0.0005 & -0.001 & 0.00009 & 0.0001 & 0.0008 & 0.0002 \\
\hline & $(0.90)$ & $(1.49)$ & $(0.86)$ & $(-0.97)$ & $(0.66)$ & $(1.01)$ & $(1.44)$ & $(0.12)$ \\
\hline \multirow[t]{2}{*}{ SDUNEMP } & $0.0001^{* * * *}$ & $0.0001^{* * * *}$ & -0.000003 & 0.0006 & $0.0001^{* * * *}$ & $0.0001^{* * * *}$ & -0.00004 & -0.0002 \\
\hline & (3.07) & (3.14) & $(-0.02)$ & $(1.61)$ & (2.94) & (2.96) & $(-0.21)$ & $(-0.47)$ \\
\hline \multirow{2}{*}{ INCOME } & $0.001^{* * * *}$ & $0.0011^{* * *}$ & $0.005^{* *}$ & 0.02 & $0.001^{* * * *}$ & $0.0011^{* * *}$ & $0.005^{* *}$ & $\mathbf{0 . 0 3}^{* * *}$ \\
\hline & $(3.41)$ & (3.26) & (2.10) & $(1.18)$ & (3.63) & (3.46) & $(\mathbf{2 . 0 0})$ & (2.12) \\
\hline \multirow[t]{2}{*}{ FOREIGN } & -0.004 & -0.01 & $0.005^{* *}$ & 0.01 & -0.005 & -0.01 & $0.004^{* * *}$ & 0.01 \\
\hline & $(-0.69)$ & $(-0.97)$ & $(2.50)$ & $(0.90)$ & $(-0.79)$ & $(-0.99)$ & $(2.24)$ & $(1.57)$ \\
\hline \multirow{2}{*}{ LOAN } & 0.0007 & 0.0007 & $\mathbf{0 . 0 0 8}^{* * * *}$ & $0.02^{*}$ & 0.0007 & 0.0008 & $0.007^{* * *}$ & $0.033^{* * *}$ \\
\hline & $(1.35)$ & $(1.36)$ & (3.20) & (1.94) & $(1.42)$ & $(1.45)$ & $(2.81)$ & (3.10) \\
\hline \multirow[t]{2}{*}{ EQUITY } & $-0.01^{* * * * *}$ & $-0.009^{* * * *}$ & -0.008 & 0.01 & $-0.01^{* * * * *}$ & $-0.01^{* * * *}$ & -0.007 & 0.005 \\
\hline & $(-5.30)$ & $(-4.94)$ & $(-1.09)$ & $(0.57)$ & $(-5.69)$ & $(-5.44)$ & $(-0.98)$ & $(0.20)$ \\
\hline \multirow[t]{2}{*}{ LIQUID_RISK } & $0.001^{* * * *}$ & $0.001^{* * *}$ & 0.003 & -0.005 & $0.001^{* * * *}$ & $0.001^{* * *}$ & 0.002 & -0.002 \\
\hline & (3.16) & (3.16) & $(1.44)$ & $(-0.58)$ & $(3.12)$ & $(3.00)$ & $(1.25)$ & $(-0.31)$ \\
\hline \multirow[t]{2}{*}{ SINGLESTATE } & 0.00004 & 0.00002 & -0.0002 & 0.002 & 0.00008 & 0.00001 & -0.0001 & $\mathbf{0 . 0 0 3}^{* *}$ \\
\hline & $(0.39)$ & $(0.18)$ & $(-0.98)$ & (1.30) & $(0.68)$ & $(0.09)$ & $(-0.57)$ & $(2.52)$ \\
\hline \multirow{2}{*}{ SINGLECOUNTY } & $0.0005^{* * * *}$ & $0.00066^{* * * *}$ & 0.0003 & & -0.0001 & -0.0001 & 0.0005 & \\
\hline & (2.79) & $(\mathbf{2 . 8 8})$ & $(0.53)$ & & $(-1.40)$ & $(-1.57)$ & $(0.87)$ & \\
\hline $\mathrm{N}$ & 44468 & 42661 & 1616 & 118 & 44468 & 42661 & 1616 & 118 \\
\hline $\mathrm{n}$ & 5983 & 5719 & 317 & 23 & 5983 & 5719 & 317 & 23 \\
\hline R2 & 0.0186 & 0.0172 & 0.125 & 0.549 & 0.0187 & 0.0174 & 0.122 & 0.567 \\
\hline K-P statistic & 342.66 & 321.64 & 23.49 & 3.54 & 306.05 & 150.91 & 28.92 & 21.35 \\
\hline J statistic & 2.80 & 3.05 & 1.76 & 6.76 & 2.77 & 1.18 & 3.74 & 1.46 \\
\hline $\begin{array}{l}\text { Marginal effect } \\
\text { z statistic }\end{array}$ & $\begin{array}{c}\mathbf{0 . 0 0 3} \\
\mathbf{3 . 7 3}\end{array}$ & $\begin{array}{c}\mathbf{0 . 0 0 4} \\
3.87\end{array}$ & NS & NS & NS & NS & NS & NS \\
\hline
\end{tabular}

